\title{
Sources and exchanges of mercury in the waters of the Northwestern Mediterranean margin
}

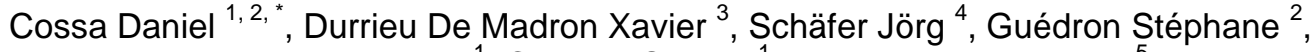 \\ Marusczak Nicolas ${ }^{1}$, Castelle Sabine ${ }^{1}$, Naudin Jean-Jacques ${ }^{5}$
}

${ }^{1}$ Ifremer, Mediterranean Centre, BP 330, F-83507 La Seyne-sur-Mer, France

${ }^{2}$ Université Grenoble Alpes, ISTerre, BP 53, F-38041 Grenoble, France

3 Université de Perpignan, Cnrs-Cefrem, 52, Ave. P. Alduy F-66860, Perpignan Cedex, France

${ }^{4}$ Université de Bordeaux, Epoc, F-33615 Pessac, France

${ }^{5}$ Université P. et M. Curie, Lobb, F-66651 Banyuls-sur-Mer, France

* Corresponding author : Daniel Cossa, email address : dcossa@ifremer.fr

\begin{abstract}
:
Ocean margins are focal regions in terms of mercury $(\mathrm{Hg})$ exchanges between the continent and the open sea. The aim of this paper is to describe the distribution and partition of $\mathrm{Hg}$ between the gaseous, dissolved and particulate phases in the waters of the Northwestern Mediterranean (NWM) margin, in order to assess the $\mathrm{Hg}$ sources and exchanges within the continuum between the continental shelf (Gulf of Lions) and the open sea (Northern Gyre).
\end{abstract}

Mean ( \pm standard deviation) of total $\mathrm{Hg}$ species $(\mathrm{HgT})$ concentrations in unfiltered water samples were $1.52 \pm 1.00 \mathrm{pmol} \mathrm{L-1}(\mathrm{n}=36)$ in the inner shelf, $1.09 \pm 0.15 \mathrm{pmol} \mathrm{L-1}(\mathrm{n}=30)$ along the slope, and $1.10 \pm$ $0.13 \mathrm{pmol} L-1(\mathrm{n}=99)$ in the Northern Gyre. The dissolved phase $(<0.45 \mu \mathrm{m})$ average concentrations were $0.80 \pm 0.47 \mathrm{pmol} \mathrm{L-1}(n=37)$ in the inner shelf, $0.93 \pm 0.20$ pmol L-1 $(n=4)$ along the slope and 0.84 $\pm 0.10(n=20)$ pmol L-1 in the Northern Gyre. The particulate fraction of Hg decreased very strongly seaward from around $60 \%$ on the shelf to $10-25 \%$ above the Northern Gyre. Very low dissolved HgT concentrations occurred in the inner shelf water, consistent with the results of incubation experiments, which demonstrated that shelf water is very efficient in both production and release of dissolved gaseous $\mathrm{Hg}$ into the atmosphere. In the North Gyre waters column HgT presents a distribution pattern inverse to that of dissolved oxygen, and a slight $\mathrm{Hg}$ enrichment in the deep layer (Western Mediterranean Deep Water).

The $\mathrm{Hg}$ from the open sea water is the largest $\mathrm{Hg}$ input to the Gulf of Lions ( $5.7 \mathrm{kmol} \mathrm{yr}-1)$, whereas inputs from the riverine source account for $\sim 3.4 \mathrm{kmol} \mathrm{yr}-1$ and atmospheric deposition for less than 0.5 $\mathrm{kmol} \mathrm{yr}-1$. The $\mathrm{Hg}$ accumulated in the sediments of the shelf is $\sim 4.5 \mathrm{kmol} \mathrm{yr}-1$, including $0.6-1.7 \mathrm{kmol}$ $\mathrm{yr}-1$ in the Rhône prodelta sediments. The evasion to the atmosphere represents a $\mathrm{Hg}$ flux of $\sim 2.6 \mathrm{kmol}$ yr-1. 


\section{Highlights}

- Distribution and fluxes of total Hg have been examined in the Gulf of Lions and North Gyre of the NW Mediterranean. Concentrations varied from 0.6 to $4.57 \mathrm{pmol} \mathrm{L}^{-1}$ on the inner shelf, and from 0.5 to 1.5

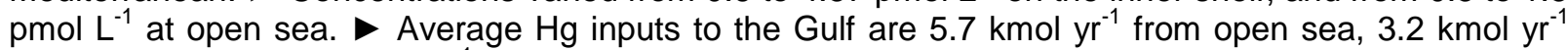

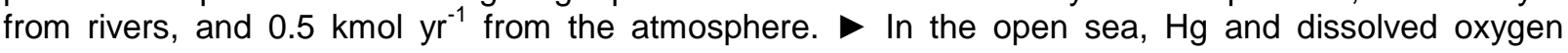
distributions are inverse.

Keywords : Mercury, Ocean margin, Coastal area, Mediterranean 


\section{Introduction}

Mercury $(\mathrm{Hg})$ is distributed in Earth's biogeochemical system between three main reservoirs: the crust (5000 Mmol), the Ocean (1780 Mmol) and the atmosphere (28 Mmol) (Mason et al., 2012; UNEP, 2013). Terrestrial emissions release volatile $\mathrm{Hg}^{0}$ into the atmosphere and direct atmospheric deposition delivers $\mathrm{Hg}^{\mathrm{II}}$ onto the ocean surface. Owing to fast redox reactions between $\mathrm{Hg}^{0}$ and $\mathrm{Hg}^{\mathrm{II}}$, $\mathrm{Hg}$ is constantly exchanged between the ocean and the atmosphere (Fitzgerald et al., 2007; Mason et al., 2012). On the other hand, man-made activities have deeply modified the natural $\mathrm{Hg}$ cycle. According to Lamborg et al. (2015), the increase in anthropogenic atmospheric emissions, over the past two centuries, has led to doubling the oceanic $\mathrm{Hg}$ amount in the thermocline waters and tripling the $\mathrm{Hg}$ content of oceanic surface waters, compared to preanthropogenic conditions. In this context, what is the role of ocean margins in the oceanic $\mathrm{Hg}$ cycle?

Ocean margins are very important regions in terms of biogeochemical exchanges, involving organic matter and trace elements, between the continent and the open sea (Walsh, 
1991; Wollast and Chou, 2001). An early global mass balance, constructed at the scale of the ocean margins, suggested that particulate $\mathrm{Hg}$ from rivers represents the largest single $\mathrm{Hg}$ flux but that direct atmospheric $\mathrm{Hg}$ deposition exceeds the dissolved $\mathrm{Hg}$ riverine inputs (Cossa et al., 1996). According to a more recent review, the cycling of $\mathrm{Hg}$ in coastal marine systems should be comparable to that in the open ocean, but with enhanced concentrations of $\mathrm{Hg}$ species (Fitzgerald et al., 2007). Indeed, in addition to atmospheric deposition, riverine discharge and mobilization from sediments can significantly contribute to the $\mathrm{Hg}$ load in coastal waters (Coquery et al., 1997; Choe and Gill, 2003; Whalin et al., 2007; Balcom et al., 2008; Muresan et al., 2008; Guédron et al., 2012; Noh et al., 2013). Other studies suggest that Hg removal processes may be boosted at the margins (Cossa et al., 1988; Gill and Fitzgerald, 1988; Cossa et al., 2004). Enhanced biological activity favors (i) scavenging removal, via $\mathrm{Hg}$ sorption on aggregating and settling biogenic particles, and (ii) atmospheric evasion, via microbiologically mediated $\mathrm{Hg}^{\mathrm{II}}$ reduction, and consequently play an important role in regulation surface water $\mathrm{Hg}$ concentrations near the slope and on the shelf. In spite of the scientific progress achieved during the past decades, the $\mathrm{Hg}$ biogeochemical coastal specificities and their influences on the global $\mathrm{Hg}$ cycling remain unassessed. More precisely, according to Mason et al. (2012), there is a need for high resolution water column profiles for $\mathrm{Hg}$ on continental margins, especially at upper slope stations, in order to understand the processes linking the biogeochemical cycling of $\mathrm{Hg}$ between coastal regions and the open ocean.

Here, we address the questions of the abundance, distribution, partitioning, sources and exchanges of $\mathrm{Hg}$ in the water masses continuum between the continent and the open sea at the Northwestern Mediterranean (NWM) margin. A companion paper addresses methylated mercury species dynamics in the same area (Cossa et al., 2017). 


\section{Study area}

The Northwestern Mediterranean is characterized by the presence of a large continental shelf and the associated slope, both constituting the Gulf of Lions (Fig. 1). The water circulation in the Gulf of Lions is influenced in the South by the Northern Current, which is a part of a current system going from the Tyrrhenian Sea up to the Alboran Sea via the Ligurian Sea (Millot and Tapier-Letage, 2005). This Northern Current flows as a major vein along the upper part of the continental slope and partially on the shelf (Fig. 1). Intrusions of the Northern Current on the Gulf of Lions shelf occur at different locations and in any season either as a separate vein of the main Northern Current or as a part of the main Northern Current core impinging on the shelf (Estournel et al., 2003; Petrenko et al., 2005). The North Gyre and the Gulf of Lions have contrasting hydrological and biological properties. The North Gyre is a typical oligotrophic open Mediterranean environment experiencing strong winter mixing of the surface and intermediate water masses, whereas the Gulf of Lions constitutes one of the few mesotrophic coastal regions within the Mediterranean Sea (Morel and André, 1991), largely influenced by the Rhône River freshwater inputs.

The Gulf of Lions covers a surface of $\sim 12 \times 10^{3} \mathrm{~km}^{2}$ (Durrieu de Madron et al., 2003) and receives riverine inputs mainly from the Rhône River, which alone drains a watershed of $10^{5} \mathrm{~km}^{2}$ with respective mean annual liquid and solid discharges of $1750 \mathrm{~m}^{3} \mathrm{~s}^{-1}$ and 2-20 $\mathrm{x}$ $10^{12} \mathrm{~g} \mathrm{yr}^{-1}$ (Pont et al., 2002, Gairoard et al., 2012, Eyrolle et al., 2012, Launay, 2014). Materials present in the Gulf of Lions waters originate from allochthonous sources (rivers and atmosphere) and from autochthonous sources (bed erosion and planktonic production). The Rhône River is the major freshwater input to the western Mediterranean and its waters 
undergo three main processes before being diluted in the Gulf of Lions water masses. First, freshwater is rapidly mixed with seawater within a few kilometers between Barcarin and the prodelta area (Fig. 1). Secondly, the Rhône River plume is driven on the shelf by variable continental winds (the northerly Mistral and southwesterly Tramontane, and southeasterlyeasterly Marin) and the cyclonic Northern Current (Fig. S1). The plume is periodically broken due to wind direction changes, engendering "Low Salinity Water" lenses drifting on the shelf as described by Naudin et al. (1997). Low Salinity Water lenses are a few kilometers in diameter and 10 to 50 m thick (Naudin et al., 1997; Diaz et al., 2008). Depending on meteorological conditions and on the density gradient induced by the freshwater-seawater mixing processes, Low Salinity Water lenses can accumulate along the coast or be transported towards the slope. Interestingly, these Low Salinity Water structures allow continuation of estuarine processes outside the Rhône delta area (Naudin et al., 1997). Thirdly, below the Rhône River plume, the dense riverine particles settle abruptly, generating large sediment accumulation in the prodelta area up to several dozens of centimeters per year in the proximal delta ( 20 m water depth; Charmasson et al. (1998), Radakovitch et al. (1999), Maillet et al. (2006) and Cathalot et al. (2010). Finer riverine material is exported farther on the Gulf of Lions shelf, undergoing a westward net transport through sedimentation/resuspension processes generated by infrequent easterly wind storm events (Durrieu de Madron et al., 2008; Ulses et al., 2008a; Guizien, 2009; Marion et al., 2010; Bourrin et al., 2015). These easterly storms induce downwelling at the southwestern end of the Gulf of Lions, especially in the Cap de Creus canyon (Palanques et al., 2006; 2009; Ulses et al, 2008a; Martin et al., 2013), and a massive export of shelf water and resuspended particulate matter to the upper slope. Furthermore, dense water, formed during winter along the coastline of the Gulf of Lions under 
the cooling effect of the Mistral and Tramontane winds (Fig. S1), also descends and exports fine sediments principally at the southern end of the shelf (Bourrin et al., 2008; Canals et al., 2006). These events, which may merge and concern thousands $\mathrm{km}^{3}$ of waters (Ulses et al., 2008a, 2008b), may coincide with the peak of the primary production on the shelf (Conan et

al., 1998), probably enhancing the vertical transport of plankton-associated metals such as $\mathrm{Hg}$. Dense water masses formed on the shelf usually reach $500 \mathrm{~m}$ depth but they can reach depth larger than $2000 \mathrm{~m}$ and contribute to the deep water formation of the western Mediterranean basin (Canals et al., 2006; Durrieu de Madron et al., 2013). Dense water formation during winter is also known to result from open-sea convection, which mixes surface Atlantic water (AW) with Levantine Intermediate water (LIW) within the North Gyre. This mixing may concern the entire water column and trigger strong currents during the spreading phase of the newly-formed Western Mediterranean Deep Water (WMDW) that can resuspend deep sediment and generate thick bottom nepheloid layers (Stabholz et al., 2013; Puig et al., 2013). Thus, linkages between the physical mechanisms, planktonic production, and resuspension of sediments lead to the transport of dissolved and particulate matter, including $\mathrm{Hg}$, from the shelf to the slope/rise and abyssal plain.

\section{Material and methods}

\subsection{Sampling}

The water samples have been collected (i) in the Rhône River and at its mouth, (ii) on the Gulf of Lions shelf, (iii) on the continental slope, and (iiii) in the North Gyre (Fig. 1), in order to document the seasonal variations of $\mathrm{HgT}$ and the behavior (partitioning) of $\mathrm{Hg}$ species during the freshwater/seawater mixing along the continuum including the Rhône River plume, 
drifting Low Salinity Water on the shelf as well as the water column above the continental slope/rise (including the Cap de Creus canyon, Fig. 1) and in the North Gyre.

\subsubsection{Atmospheric deposition}

Thirteen rain events were collected for HgT determinations between April 2009 and January

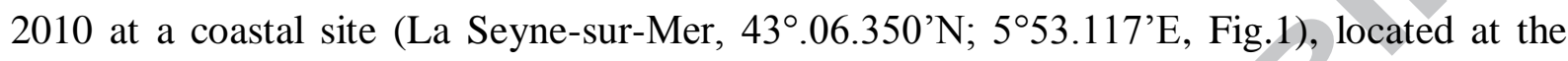
eastern end of the Gulf of Lions. The samples were transferred into acid-washed $125 \mathrm{~mL}$ Teflon (FEP) bottles and acidified without filtration $\left(0.4 \% \mathrm{v} / \mathrm{v} \mathrm{HCl}\right.$, SupraPur, Merck $\left.{ }^{\circledR}\right)$ just after the water collection. The rain collecting device (PP040, MTX $^{\circledR}$ ) was located 15 m above sea level. Details of the sampling are given by Castelle (2010). At the same site, 28 aerosol samples were collected on cellulose acetate membranes $(0.22 \mu \mathrm{m})$ from July 2009 to March 2010. Each sample represents one week of pumping at a pumping rate of $14 \mathrm{~L} \mathrm{~min}^{-1}$. Total gaseous $\mathrm{Hg}$ concentrations in the atmosphere were monitored at the same time (Marusczak et al., 2015).

\subsubsection{Rhône River monitoring}

Rhône River $\mathrm{Hg}$ monitoring was performed at Arles (Sta. SORA, Fig. 1) during two monitoring periods: (i) a period of low waters from March, 2009 to June, 2010, with only one moderate flood event $\left(\sim 3000 \mathrm{~m}^{3} \mathrm{~s}^{-1}\right.$ on December the 2nd), and (ii) during the flooding period of October-November 2008 (up to $3580 \mathrm{~m}^{3} \mathrm{~s}^{-1}$ ). Freshwater samples were collected twice a month at Station SORA by pumping through polyethylene tubing using an all-Teflon (PFA) double-bellows pump (10-LPM, ASTI $\left.{ }^{\circledR}\right)$. Samples were collected in acid washed 2L Teflon (FEP) bottles then filtered through hydrophilic Teflon membranes (LCR, Millipore ${ }^{\circledR}$ ) with a porosity of $0.45 \mu \mathrm{m}$. Membranes were stored at $-18^{\circ} \mathrm{C}$ in polycarbonate Petri dishes and the 
filtrates were acidified $\left(0.4 \% \mathrm{v} / \mathrm{v} \mathrm{HCl}\right.$, SupraPur, Merck $\left.^{\circledR}\right)$ and stored in acid washed $500 \mathrm{~mL}$ Teflon (FEP) bottles.

\subsubsection{Rhône delta mixing zone}

Brackish water samples were collected on $16^{\text {th }}$ and $17^{\text {th }}$ October 2008 between Barcarin (Rhône River) and the sea using a rubber boat (Fig.1; the precise locations of the stations are indicatedi Table S1). The samples were collected, directly (by glove-covered hands) into acid washed 2L Teflon (FEP) bottles, filtered and stored as described in the previous section.

\subsubsection{BIOPRHOFI cruise}

During the BIOPROHFI cruise $\left(14^{\text {th }}-27^{\text {th }}\right.$ May 2006), two types of water masses were sampled: (i) the productive shelf water and (ii) the mesotrophic slope water. In the first case, two Low Salinity Water lenses, originating from the Rhône River plume, were successively tracked using a Lagrangian sampling protocol: lens " 1 " between May $14^{\text {th }}$ and $18^{\text {th }}$, corresponding to stations S1 to S68 and lens " 2 " between the $19^{\text {th }}$ and $26^{\text {th }}$, corresponding to stations S88 to S220 (Fig. S2). In the lenses, the 0-50 m layer was systematically sampled; the height of the water column varied between 60 and $100 \mathrm{~m}$ during the drifting. For the second type, two deep casts $(0-900 \mathrm{~m})$ were performed on May the $26^{\text {th }}$ at the slope foot (Stas. S221 and S230, Fig. S2); their coordinates are given in Table S1.

\subsubsection{CASCADE cruise}

During the CASCADE cruise $\left(1^{\text {st }}-23^{\text {th }}\right.$ March 2011), water was collected (i) on the inner shelf from the Rhône prodelta to the south-western end of the Gulf of Lions (Stas. A to D), (ii) at the head of Cap de Creus canyon (Stas. E and X), and (iii) by means of thirteen deep casts on the shelf edge (Stas. L-01 and M-12), the slope foot (Stas. L-03 and M-10) and within the 
North Gyre (Stas. Antarès, S2400, L-05-08-10-12 and M-03-05-08). Stations at the head of the Cap de Creus canyon and within the North Gyre water column were sampled during a storm-induced downwelling event and a convective event, respectively (Fig. 1). Two to twelve water depths were sampled for each cast, depending on the height of the water column. Sampling station locations are given in Figure 1 and their coordinates in table S1.

\subsection{Sample treatment}

The nomenclature used in the following text, i.e. $X_{\mathrm{UNF}}, X_{\mathrm{F}}$ and $\mathrm{X}_{\mathrm{P}}$ refer to the unfiltered, "dissolved" $(<0.45 \mu \mathrm{m})$ and particulate fractions, respectively (with $\mathrm{X}$ being a distinct $\mathrm{Hg}$ species), whereas $\mathrm{HgT}$ refers to total $\mathrm{Hg}$ (including all methylated and inorganic species).

The samples from the 0-50 m layer of the shelf water masses (BIOPRHOFI cruise) were collected by pumping with an all-Teflon (PFA) double-bellows pneumatic pump (102PMPFD-1, ASTIß) through polyethylene tubing, directly into a Class 100 clean container, with the consequence that the seawater was never in contact with the atmosphere of the ship. All the plastic wares were previously acid-cleaned according to ultraclean sample handling protocols (e.g., Cossa et al. 2003). Discrete water samples were collected in 2L Teflon (FEP) bottles inside the container, where filtrations were then performed on sub-samples using acid washed polycarbonate membranes $\left(0.45 \mu \mathrm{m}\right.$, Nuclepore $\left.{ }^{\circledR}\right)$. Filtrates were collected in Teflon (FEP) bottles and acidified with $\mathrm{HCl}\left(0.4 \%\right.$, v/v, Suprapur, Merck $\left.{ }^{\circledR}\right)$ for $\mathrm{HgT}_{\mathrm{F}}$ analyses.

Samples for dissolved gaseous Hg (DGM) analyses were collected in a 1L Teflon bottle (FEP) according to the traditional method used for dissolved oxygen determination in order to avoid gas evasion during the collection (Hood et al. 2010). Deep-water samples (> $50 \mathrm{~m}$ ) were collected during the BIOPRHOFI and CASCADE cruises by rosette-mounted 5L bottles (1010X- 
Niskin, General Oceanics ${ }^{\circledR}$ ) equipped with a CTD probe. These samples were not filtered and analyzed only for $\mathrm{HgT}_{\mathrm{UNF}}$. Dissolved gaseous $\mathrm{Hg}$ and $\mathrm{HgT}$ were determined on board.

\subsection{Chemical analyses}

\subsubsection{Total mercury}

Total $\mathrm{Hg}$ in filtered and unfiltered samples were measured on board within a few minutes after sampling. In order to access all the $\mathrm{Hg}$ chemical species present in the sample, the release of $\mathrm{Hg}$ from its ligands was achieved by a $\mathrm{BrCl}$ solution $(0.1 \mathrm{~mL}$ of a $0.2 \mathrm{M}$ solution is added to a $100 \mathrm{~mL}$ sample), and then the $\mathrm{Hg}^{\mathrm{II}}{ }_{\mathrm{i}}$ was reduced to $\mathrm{Hg}^{0}$ with an acidic $\mathrm{SnCl}_{2}$ solution $(0.2 \mathrm{~mL}$ of a $1 \mathrm{M}$ solution is added to a $100 \mathrm{~mL}$ sample). This technique, now known as the US-EPA standard method $\mathrm{N}^{\circ} 1631$, derives from the original Bloom and Crecelius (1983) method and has been described in detail by several authors (e.g., Gill and Fitzgerald,

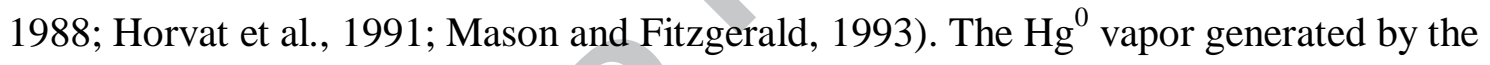
reduction is amalgamated on a gold ( $\mathrm{Au}$ ) trap, then released by heating into an Atomic Fluorescence Spectrometer $\left(2500\right.$, Tekran $\left.^{\circledR}\right)$. The detection limit (DL) was $0.1 \mathrm{pmol} \mathrm{L}^{-1}$ and the reproducibility varied according to the concentration level between 5 and $15 \%$ (Cossa et al. 2003). The accuracy of HgT measurements was tested using the ORMS-3 certified reference material (CRM) from the National Research Council of Canada. Our measurements were always within the confidence limits given for the CRM $\left(12.6 \pm 1.1 \mathrm{pg} \mathrm{mL}^{-1}\right.$; http://inmsienm.nrc-cnrc.gc.ca/calserv/crm_files_f/ORMS-3_f.pdf).

\subsubsection{Dissolved gaseous mercury}

For analysis of DGM, $300 \mathrm{~mL}$ of sample was purged during 30 min with ultra-high purity nitrogen previously stripped of $\mathrm{Hg}^{0}$ by passage through $\mathrm{Au}$ traps, at a flow rate of $300 \mathrm{~L} \mathrm{~min}^{-}$ 
${ }^{1}$, corresponding to a calculated extraction rate of $78 \%$ (results were corrected for this yield). Volatilized $\mathrm{Hg}$ species were trapped and concentrated on an Au trap, subsequently desorbed by thermo-desorption and quantified by gas-phase AFS. Dissolved gaseous $\mathrm{Hg}$ net production kinetics were evaluated by incubating unfiltered water samples in an incubator located on the deck of the vessel exposed to sunlight radiations under temperature control achieved by continuously pumping sea-surface water through the incubator using a through-flow system. These ex-situ incubations were performed in batch experiments during 2 to $12 \mathrm{~h}$ periods in the absence of light (FEP Teflon bottles, wrapped in aluminium foil) and in the presence of light (unwrapped FEP Teflon bottles). The two series of experiments allowed to identify the part of photoreduction in the DGM net production and to estimate the DGM production. Transparent FEP Teflon bottles absorbed only $2.5 \%$ of total incident radiation according to Amyot et al. (1997). Net DGM production was estimated without taking into account the possible reoxidation of $\mathrm{Hg}^{0}$.

\subsubsection{Phosphorus}

Soluble reactive phosphorus (SRP) was determined in seawater with an auto-analyzer using the standard molybdate blue method (Murphy and Riley, 1962) as detailed in the protocol by Aminot and Kérouel (2007). Particulate phosphorus $\left(\mathrm{P}_{\mathrm{P}}\right)$ determination used the same colorimetric method but after magnesium nitrate oxidation (Ormaza-Gonzalez and Statham, 1996).

\section{RESUlts}

\subsection{Rain and aerosol}


Total $\mathrm{Hg}$ concentrations in rain water (bulk precipitation) varied from 10 to $80 \mathrm{pmol} \mathrm{L}^{-1}$, with a mean of $31 \pm 22 \mathrm{pmol} \mathrm{L}^{-1}(\mathrm{n}=13)$. This range is similar to those published for other coastal areas of the Northern hemisphere (e.g., Hammerschmidt et al., 2007; Marusczak et al., 2011; Weiss-Penzias et al., 2012). The average HgT concentration calculated here for the period 2009-2010, is more than 2 times lower than that calculated for the 40 rain events sampled between January 2002 and May 2003 in a coastal site of Corsica (Northwestern Mediterranean), namely $70 \pm 100 \mathrm{pmol} \mathrm{L}^{-1}$ (Cossa and Coquery, 2005). Total Hg concentrations in the 28 aerosol samples varied between 0.1 and $35.0 \mathrm{nmol} \mathrm{g}^{-1}$ with a mean of $6.9 \pm 6.7 \mathrm{nmol} \mathrm{g}^{-1}$. Dissolved gaseous $\mathrm{Hg}$ was not measured in rain samples.

\subsection{Rhône River and its plume}

During the low flow period of the Rhône River, $\operatorname{HgT}_{\mathrm{F}}$ and $\mathrm{HgT}_{\mathrm{P}}$ concentrations varied in the picomolar range (Table 1). Mercury was predominantly (95\%) associated with suspended particles and its solid-solution partition $(\mathrm{KdHg})$ was controlled by the one of organic carbon (Fig. 2, insert). On the other hand, $\mathrm{HgT}_{\mathrm{P}}$ depicted a negative relationship with water discharge (Fig. 2). The variation of dissolved $\mathrm{Hg}$ concentrations $\left(\mathrm{HgT}_{\mathrm{F}}\right)$ during the mixing of Rhône freshwater with Gulf of Lions saltwater, between the Barcarin site and the prodelta area, is illustrated in Figure 3a. Concentrations of $\mathrm{HgT}_{\mathrm{F}}$ varied from 0.6 to $4.2 \mathrm{pmol} \mathrm{L}^{-1}$, and tended to be higher in freshwater than in marine water samples $\left(\operatorname{HgT}_{\mathrm{F}} v s\right.$ Salinity, $\left.p<0.1\right)$. The $\operatorname{HgT}_{\mathrm{F}}$ concentrations in Low Salinity Water lenses $(1-50 \mathrm{~m})$ drifting on the shelf were in a similar range (0.6-3.5 pmol L ${ }^{-1}$, Table 2, Fig. 3b). Their mean concentration $\left(1.57 \mathrm{pmol} \mathrm{L}^{-1}\right)$ was $36 \%$ lower $(t$-test, $p<0.01)$ than the $\operatorname{HgT}_{\mathrm{F}}$ mean concentration in the Rhône River $\left(2.45 \mathrm{pmol} \mathrm{L}^{-1}\right)$. Within the water lenses, $\mathrm{HgT}_{\mathrm{F}}$ temporal variations were roughly synchronal with the sampling depth, with a sinusoidal-type shap in lense 1 (Fig. S3). In the lenses, total $\mathrm{Hg}$ was equally 
distributed between the dissolved and particulates phases, with an average $\mathrm{HgT}_{\mathrm{F}} / \mathrm{HgT}_{\mathrm{P}}$ ratio of 0.49 .

Dissolved gaseous $\mathrm{Hg}$ concentrations were measured at $5 \mathrm{~m}$ depth during 18 hours-long time series $\left(20^{\text {th }}\right.$ and $21^{\text {rst }}$ May) and on three vertical profiles within the Low Salinity Water lenses (Fig. S4). Along the DGM profiles, the concentrations varied from 0.02 to $0.45 \mathrm{pmol} \mathrm{L}$ 1, averaging $0.09 \pm 0.11 \mathrm{pmol} \mathrm{L}^{-1}(\mathrm{n}=37)$, whereas for the time series they varied from 0.04 to 0.33 pmol $\mathrm{L}^{-1}$, averaging $0.13 \pm 0.09 \mathrm{pmol} \mathrm{L}^{-1}(\mathrm{n}=10)$. These ranges are similar to those reported by other authors for the Mediterranean Sea and other parts of the world ocean (e.g., Mason et al., 1998; Laurier et al., 2003; Andersson et al., 2006; Wängberg et al., 2008). Vertical DGM profiles showed a downward increase in concentrations from surface to $50 \mathrm{~m}$ at station S88 and S95; while a surface maximum was superimposed to this tendency at S108 (Fig. S4). The time series measurements produced the classical pattern of low DGM values during the night and higher levels during the day (insert, Fig. S4). Ex-situ incubation experiments showed clearly higher DGM production when exposed to sun light (0.021-0.058 pmol $\left.\mathrm{L}^{-1} \mathrm{~h}^{-1}\right)$ compared to DGM production in the dark $\left(0.006-0.032 \mathrm{pmol} \mathrm{L}^{-1} \mathrm{~h}^{-1}\right)$.

Normalized to HgT, reduction rates were $1.3-4.5 \% \mathrm{~h}^{-1}$ and $0.7-3.4 \% \mathrm{~h}^{-1}$ for light and dark conditions, respectively.

\subsection{Shelf and slope}

The inner shelf (Stas. A-08, B-08, C-08 and D-09, 0-100 m bottom depth) and slope edge (Stas. E-06, L-01 and M-12, 100-300 m bottom depth) water columns were explored in March 2011 (CASCADE cruise). On the shelf, average concentrations $\mathrm{HgT}_{\mathrm{UNF}}$ and $\mathrm{HgT}_{\mathrm{F}}$ were $1.52 \pm$ $1.00(\mathrm{n}=36)$, and $0.80 \pm 0.47(\mathrm{n}=37) \mathrm{pmol} \mathrm{L}^{-1}$, respectively (Fig. 4a). The dissolved HgT contributed roughly $58 \%$ of $\mathrm{HgT}_{\mathrm{UNF}}$ (Table 3 ), yielding an average $\mathrm{HgT}_{\mathrm{F}} / \mathrm{HgT}_{\mathrm{P}}$ ratio of 1.11 . 
Concentrations were highest along the A transect, i.e. the nearest to the Rhône River prodelta, especially at surface in the brackish water plume (Table 3, Fig. 4a). Elsewhere, vertical HgT profiles (Fig. 4a) were relatively uniformous whatever the depth for both filtered and unfiltered samples. Interesting to note are the very low concentrations $\left(<1 \mathrm{pmol} \mathrm{L}^{-1}\right)$ of $\mathrm{HgT}_{\mathrm{F}}$ on the inner shelf, especially at Stas. B, C and D (Table 3). Figure $4 \mathrm{~b}$ shows the time variations observed at the head of Cap de Creus canyon (Sta. X) during the monitored eastern storm event. Conversely to the shelf profiles, we observed a significant increase of $\mathrm{HgT}_{\mathrm{UNF}}$ toward the bottom for Sta. X (Fig. 4b), a feature likely linked to shelf sediment resuspension and downslope export occurring during the storm.

At the base of the continental slope (Stas. S-230, L-03 and M-10), concentrations of $\mathrm{HgT}_{\mathrm{UNF}}$ ranged from 0.78 to $1.53 \mathrm{pmol} \mathrm{L}^{-1}$ with no clear differences between the two cruises (Fig. S5). With the exception of two high values at the surface, $\operatorname{HgT}_{\mathrm{UNF}}$ was significantly $(p<0.05)$ higher below than above $100 \mathrm{~m}$ depth, suggesting removal in upper layer and regeneration below. The few DGM concentrations $(n=6)$ measuredin surface water from the slope ranged from 0.05 to $0.09 \mathrm{pmol} \mathrm{L}^{-1}$ and never exceeded $12 \%$ of the respective $\mathrm{HgT}_{\mathrm{UNF}}$.

\subsection{North Gyre}

Temperature and salinity transects are illustrated in Figure 5. The main oceanographical feature was the presence of a high-temperature high-salinity layer between 200 and $500 \mathrm{~m}$ depth corresponding to LIW, i.e. a water mass from the Eastern Mediterranean Basin. The measured $\mathrm{HgT}_{\mathrm{UNF}}$ concentrations varied from 0.53 to $1.45 \mathrm{pmol} \mathrm{L}^{-1}$, averaging $1.11 \pm 0.13$ pmol L $\mathrm{L}^{-1}(\mathrm{n}=96)$. This concentration range is similar to those measured in 2004 in the Northwestern Mediterranean (Cossa and Coquery, 2005). Figure 5 illustrates the spatial distributions of $\operatorname{HgT}_{\mathrm{UNF}}$ along the South-North and West-East transects in the North Gyre 
water column. Maximum and minimum $\mathrm{HgT}_{\mathrm{UNF}}$ concentrations occurred within the uppermost $100 \mathrm{~m}$, whereas below $500 \mathrm{~m}$ depth, the concentrations were rather uniformous with an average of $1.12 \pm 0.06 \mathrm{pmol} \mathrm{L}^{-1}(\mathrm{n}=67)$. Interestingly, dissolved oxygen and $\mathrm{HgT}_{\mathrm{UNF}}$ distributions showed opposite patterns, especially when stratification of the water column was well established. In fact, the high $\mathrm{HgT}_{\mathrm{UNF}}$ values coincided with low dissolved oxygen levels, which develop within the high salinity LIW, due to water stratification, (Fig. 5). Two profiles (L-05 and L-10) were also analyzed for total dissolved $\mathrm{Hg}\left(\mathrm{HgT}_{\mathrm{F}}\right)$. Particulate $\mathrm{Hg}\left(\mathrm{HgT}_{\mathrm{P}}\right)$ concentrations were calculated as the difference between $\mathrm{HgT}_{\mathrm{UNF}}$ and $\mathrm{HgT}_{\mathrm{F}}$ (Table S2). The dissolved HgT fraction constituted 74 to $91 \%$ of the $\mathrm{HgT}_{\mathrm{UNF}}$, with lowest $\mathrm{HgT}_{\mathrm{F}}$ concentrations occurring in the uppermost $100 \mathrm{~m}$ (Fig. 6). As a corollary, $\mathrm{HgT}_{\mathrm{P}} / \mathrm{HgT}_{\mathrm{F}}$ ratios were generally between 0.1 and 0.35 , but reached 0.45 at the surface.

Only one profile of DGM was performed in the North Gyre (Sta. S2400), with concentrations ranging from 0.05 to $0.14 \mathrm{pmol} \mathrm{L}^{-1}$ between the surface and $500 \mathrm{~m}$ depth. Between $500 \mathrm{~m}$ and $2500 \mathrm{~m}$ depth, the obtained values were being relatively constant, with a mean of $0.14 \pm 0.04 \mathrm{pmol} \mathrm{L}^{-1}(\mathrm{n}=4)$. This overall distribution was similar to that reported for the NWM (Ferrarra et al., 2003).

\section{DISCUSSION}

\subsection{Sources and sinks of Hg on the shelf}

\subsubsection{The open sea source}

The Northern Current is the main water supplier for the Gulf of Lions. The horizontal flux across the shelf-open sea boundary has been estimated to vary at different periods of 
the year between 0.07 and $0.35 \times 10^{6} \mathrm{~m}^{3} \mathrm{~s}^{-1}$ (Durrieu de Madron et al., 2003). The same authors also estimate that the shelf-slope water exchange represents $\sim 10 \%$ of the alongslope transport, namely $0.2 \times 10^{6} \mathrm{~m}^{3} \mathrm{~s}^{-1}$. The chemical characteristics of seawater entering the shelf are well represented in the 0-100 m water layer at Sta. Antarès (Fig. 1), where $\mathrm{HgT}_{\mathrm{UNF}}$ mean concentration is $0.92 \pm 0.07 \mathrm{pmol} \mathrm{L}^{-1}(\mathrm{n}=3)$. Based on these data, the estimated mean flux of $\mathrm{Hg}$ entering the shelf area via the Northern Current, mainly as

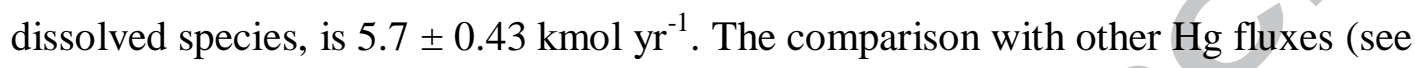
below) clearly suggests that the open sea is the main $\mathrm{Hg}$ source for the Gulf of Lions. Similar conclusions have been drawn for other coastal areas, including the Gulf of Main and the Gulf of Mexico (e.g., Sunderland et al., 2012; Harris et al., 2012).

\subsubsection{Gross and net river inputs}

Riverine $\mathrm{Hg}$ inputs mainly derive from the Rhône River solid discharges. Other Gulf of Lions rivers account for less than $15 \%$ of the total riverine particulate inputs (Gairoard et al., 2012). Concentrations of $\mathrm{HgT}_{\mathrm{P}}$ tended to decrease with increasing Rhône River discharge during the 2009-2010 monitoring period, which was characterized by the absence of large flooding events (Fig. 2). This type of relationship between $\mathrm{Hg}$ and water discharge has commonly been observed in rivers under various hydrological regimes (e.g., Coquery et al., 1997; Quémerais et al., 1999) and was attributed to seasonal changes in the nature of the particles carried in freshwater. For example, $\mathrm{HgT}_{\mathrm{P}}$ is correlated with the chlorophyll content of the particles in the Loire River (Coquery et al., 1997), suggesting $\mathrm{Hg}$ enrichment in the phytoplankton. In the Rhône River, $\mathrm{Hg}$ partitioning is governed by organic carbon distribution (Fig. 2, insert) and phytoplankton is abundant 
during low summer discharge, whereas minerals (usually less enriched in $\mathrm{Hg}$ ) dominate during floods due to erosion and bed resuspension, (Harmelin-Vivien et al., 2010).

The gross fluxes of $\mathrm{Hg}$ exported by the Rhône River are estimated to be $0.13 \mathrm{kmol}$

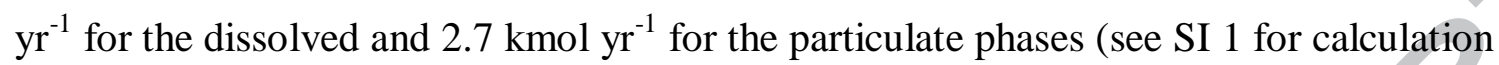
details). According to Gairoard et al. (2012), the Rhône River contributes 85 \% of the total riverine freshwater and $83 \%$ of the total riverine particle discharge to the Gulf of Lions. Thus, if we hypothesize that other riverine outputs into the Gulf of Lions have $\mathrm{Hg}$ compositions similar to that of the Rhône River, the total $\mathrm{Hg}$ input from riverine sources to the Gulf of Lions water can be estimated at 0.15 and $3.2 \mathrm{kmol} \mathrm{yr}^{-1}$ for the dissolved and particulate phases, respectively. There seems to be a clear temporal trend of riverine inputs to the NWM, as our calculated dissolved $\mathrm{HgT}$ flux value $\left(0.15 \mathrm{kmol} \mathrm{yr}^{-1}\right)$ is more than 3 times lower than a previous flux estimate based on the 1994-1995 monitoring period (Cossa and Coquery, 2005) and more than 10 times lower than the estimate proposed at the end of the eighties (Cossa and Martin, 1991). This time-trend is supported by the vertical distribution patterns of $\mathrm{HgT}$ concentrations recorded in sediments from the Rhône prodelta (Cossa et al., this issue) or in the Pierre Blanche Lagoon (Elbaz-Poulichet et al., 2011), which all show decreasing Hg concentrations since the 1960s. It should be noted that this calculation did not take into account the submarine groundwater discharge to the Gulf of Lions, estimated to be $2-30 \%$ of the Rhône River runoff (Ollivier et al., 2008), which may be a non-negligible, yet not quantified, $\mathrm{Hg}$ source for the coastal water bodies (e.g., Laurier et al., 2007). For comparison purpose, it is interesting to note that the annual $\mathrm{Hg}$ inputs from the waste water treatment plant of the City of Marseille (850 000 
inhabitants) have been approximated to be $0.016 \mathrm{kmol}$, with $75 \%$ in the particulate phase (Jany and Zebraki, 2012).

The distribution pattern of $\mathrm{HgT}_{\mathrm{F}}$ versus salinity during the freshwater-seawater mixing (Fig. 3) shows highly variable concentrations at low salinities, but fails to evoke any departure from a conservative mixing pattern, similarly with the behaviour of most other trace elements studied in the water of the Rhône Delta (Elbaz-Poulichet et al., 1996). The estuarine water escapes the mouth of the Rhône River as a turbid desalted plume that is advected, as Low Salinity Water lenses, along the Gulf of Lions shelf and the upper slope (Naudin et al., 1997). The Low Salinity Water lesnses constitute quite isolated water masses, in which the average $\operatorname{HgT}_{\mathrm{F}}$ concentrations were $36 \%$ lower ( $t$-test, $p<0.01$ ) than the $\operatorname{HgT}_{\mathrm{F}}$ mean concentration in the Rhône River waters, 49 \% higher $(t$-test, $p<0.01)$ than the $\mathrm{HgT}_{\mathrm{F}}$ mean concentration calculated for the entire Gulf of Lions shelf water, but not significantly different ( $t$-test, $p<$ 0.01) from that in the prodeltaic zone (Sta. A) (Table 3). However, the Hg distribution in the Low Salinity Water lenses does not support any removal or mobilization of dissolved HgT (Fig. 3b, Fig. S3). Based on HgT partition and behavior during the estuarine mixing, occurring in the plume and in the Low Salinity Water lenses, the gross Rhône River dissolved Hg flux can be considered as similar to the net input flux into the Northwestern Mediterranean. Bearing in mind dissolved $\mathrm{Hg}$ species are readily available for uptake by phytoplankton, it is interesting to note from an ecological point of view that, within the Gulf of Lions shelf, the dissolved $\mathrm{HgT}$ flux from riverine source represents only $2.6 \%$ of the $\mathrm{HgT}$ flux derived from the marine source.

\subsubsection{Export and accumulation on the shelf}

The fate of particulate $\mathrm{Hg}$ in the Rhône River plume and on the shelf, depends on the type of 
suspended material involved. Generally, in rivers, the coarser particles have lower $\mathrm{Hg}$ concentrations (e.g., Guédron et al., 2012). Coarse material settles down near the Rhône River mouth, mostly at 4-5 m depth (Maillet et al, 2006; Marion et al, 2010; Pruski et al, 2015). Conversely, $\mathrm{Hg}$-rich particles are likely present in the Rhône plume and within its well described, associated benthic nepheloid layer (Naudin and Cauwet, 1997; Durrieu de Madron et al., 2000; Many et al., 2016). The plume is transported together with the Low Salinity Water lenses, whereas the nepheloid layer progressively builds a seaward-drifting muddy sediment layer (Marion et al., 2010). Based on the burial efficiency of riverine particles in the sediment prodelta, varying from 20 to $54 \%$ under various hydrological regimes (Noël, 1996; Maillet et al., 2006; Dufois, 2008; Lansard, 2005; Pastor et al., 2011; Dufois et al., 2014), the estimated quantity of $\mathrm{Hg}$ currently buried in the prodelta sediments is in the range 0.64-1.73

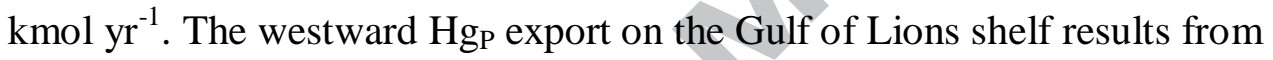
sedimentation/resuspension processes primarily related to eastern storms (Ulses et al., 2008b; Marion et al, 2010; Dufois et al, 2014), and from dispersion within the benthic nepheloid layer (Lansard et al, 2006). This material eventually reaches the head of the Cap de Creus canyon at the southwestern end of the Gulf of Lions, from where it may be exported to the slope during dense shelf water cascading or downwellings induced by storms events. For example, the 3days storm that occurred during the CASCADE cruise, on 12-15 March 2011, was recorded at Sta. X at the head of Cap de Creus canyon (Fig. 1). Based on present results and an estimated downwelling mass flux of $0.4 \times 10^{12} \mathrm{~g}$ (Bourrin et al., 2015; Dumas et al., 2014), the amount of $\mathrm{Hg}$ exported this way during the recorded event was $0.2 \mathrm{kmol}$. On the other hand, the $\mathrm{Hg}$ associated with suspended material escaping the shelf represents around $0.32 \mathrm{kmol} \mathrm{yr}^{-1}$ or 10 \% of the Rhône River inputs, according to the sedimentary budget established by Dufois et al. 
(2014) and Hg concentrations determined here. Accordingly, our results suggest that one downwelling event, such as the one recorded in March 2011, can account for a large proportion (i.e., 62\%) of the annual particulate $\mathrm{Hg}$ exported seawards from the Gulf of Lions.

The Hg accumulated in the sediments of the shelf can be roughly estimated to be $\sim 4.5$ $\mathrm{kmol} \mathrm{yr}^{-1}$, based on a mean sediment accumulation of $\sim 0.1 \mathrm{~g} \mathrm{~cm}^{-2} \mathrm{yr}^{-1}$ (Durrieu de Madron et al., 2000) and a mean $\mathrm{Hg}$ concentration in the surface shelf sediment of $\sim 0.375 \mathrm{nmol} \mathrm{g}{ }^{-1}$ (unpublish results).

\subsubsection{Atmosphere/water exchanges}

Based on a mean $\mathrm{Hg}$ concentration in rain of $31 \mathrm{pmol} \mathrm{L}^{-1}$, a precipitation average of $332 \mathrm{~mm}$ $\mathrm{yr}^{-1}$ (Lebeaupin Brossier et al., 2012) and a surface area of $12 \times 10^{3} \mathrm{~km}^{2}$ (Durrieu de Madron

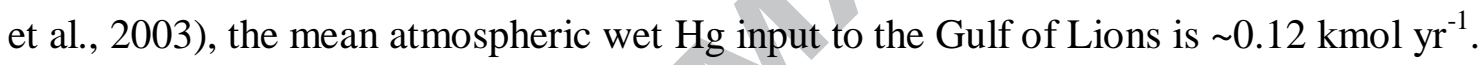
According to Vincent et al. (2016), the aerosol deposition fluxes for 1-year measurements ranged from 0.9 to $7.4 \mathrm{~g} \mathrm{~m}^{-2} \mathrm{yr}^{-1}$ from North to South of the Western Mediterranean. We chose the median value to calculate the $\mathrm{Hg}$ dry deposition on the Gulf of Lions. Using a mean $\mathrm{Hg}$ concentration in aerosols of $6.9 \mathrm{nmol} \mathrm{g}^{-1}$, the mean atmospheric dry input of $\mathrm{Hg}$ to the Gulf of Lions is $\sim 0.33 \mathrm{kmol} \mathrm{a}^{-1}$, which is almost 3-times higher than the total wet deposition. According to Zagar et al. (2013) modelling Hg deposition onto the entire Mediterranean Sea, with MECAWEx model, gave also a dry to wet ratio greater than 1 . More recent modelling gives a ratio close to 1 (Gencarelli et al., 2015).

Photoreduction and biologically mediated reduction appear to be the most likely DGM sources for the shelf water (Fig. S4). A photoreduction mechanism, as described by Amyot et al. (1997), is supported by the occurrence of a clear DGM maximum during the day-light period (see insert in Fig. S4). From incubation experiments we calculated DGM production 
rates from 16 to $58 \mathrm{fmol} \mathrm{L}^{-1} \mathrm{~h}^{-1}$ in light and from 6 to $35 \mathrm{fmol} \mathrm{L}^{-1} \mathrm{~h}^{-1}$ in dark conditions. A 2fold increase of reduction under light conditions, compared to dark conditions, clearly suggests that photochemistry (at least) equals biologically mediated reduction (Fig. S6), as already suggested for coastal water masses in other areas of the global ocean (e.g., Amyot et al., 1997; Fitzgerald and Lamborg, 2005). In fact, our results clearly suggest that in the present experimental conditions photochemistry (at least) equalled biologically mediated reduction.

From our measurements and using an empirical gas exchange model (Wanninkhof, 1992), - with a piston velocity of $5 \mathrm{~m} \mathrm{day}^{-1}$, a total gaseous $\mathrm{Hg}$ concentration in the atmosphere of $11 \pm 3 \mathrm{pmol} \mathrm{m}^{-3}$ (Marusczack et al., 2015) and a mean DGM concentration in seawater of $\sim 150 \mathrm{pmol} \mathrm{m}^{-3}$ - we calculate a $\mathrm{Hg}$ evasion rate from surface waters to the atmosphere of $0.6 \mathrm{nmol} \mathrm{m} \mathrm{m}^{-2}$. This estimate is in the high range of the values calculated by Andersson et al. (2006) for the entire Mediterranean (0.2-0.6 $\left.\mathrm{nmol} \mathrm{m}^{-2} \mathrm{~d}^{-1}\right)$. Applying these values to the Gulf of Lions shelf area $\left(12 \times 10^{3} \mathrm{~km}^{2}\right)$ gives an annual evasional $\mathrm{Hg}$ flux to the atmosphere of $\sim 2.6 \mathrm{kmol} \mathrm{yr}^{-1}$, which is equivalent to almost one half of the $\mathrm{Hg}$ inputs from marine sources to the Gulf of Lions $\left(5.7 \mathrm{kmol} \mathrm{yr}^{-1}\right)$. This atmospheric evasion flux consistently accounts for the low concentrations of dissolved $\mathrm{Hg}\left(<1 \mathrm{pmol} \mathrm{L}{ }^{-1}\right)$ found in the shelf water at the stations B, C and D (Fig. 4). Thus, the shelf clearly is an area of intense Hg evasion to the atmosphere.

\subsection{Mercury enrichment in the WMDW}

The North Gyre waters are separated from coastal waters by the Northern Current, which continuously flows along the slope (Fig. 1). Water bodies in the North Gyre normally consist of WMDW underlying LIW and AW. During the first days of the CASCADE cruise 
(encompassing Stas. L-05, L-08 and S2400), the water column in the North Gyre was still rather well mixed following a strong storm with northerly wind directions, and WMDW occupied the convection region (Fig 5). Then, the water column rapidly restratified due to the advection of surrounding LIW and AW over the convective region as observed for Stas. Antares, L-10, L-12, M-01, M-03, M-05, M-08, and the WMDW was confined to depths greater than $1000 \mathrm{~m}$. Based on the measurements in the samples from all depths sampled in the well-mixed water column and those in the samples collected deeper than $1000 \mathrm{~m}$ for the stratified water columns, we obtained an average $\mathrm{HgT}_{\mathrm{UNF}}$ concentration of $1.11 \pm 0.06 \mathrm{pmol} \mathrm{L}^{-1}(\mathrm{n}=60)$. This value is slightly but significantly higher $(t$-test, $p<0.01)$ than the average $\mathrm{HgT}_{\mathrm{UNF}}$ concentration in the LIW, which is $1.01 \pm 0.08 \mathrm{pmol} \mathrm{L}^{-}$ ${ }^{1}(\mathrm{n}=18)$ according to Cossa and Coquery (2005). Recent measurements performed in AW collected west of the Gibraltar Strait $\left(35^{\circ} 30.82^{\prime} \mathrm{N} ; 09^{\circ} 09.21^{\prime} \mathrm{W}\right)$ provided $\mathrm{HgT}_{\mathrm{UNF}}$ concentrations varying from 0.2 and $0.3 \mathrm{pmol} \mathrm{L}^{-1}(\mathrm{n}=4)$ between the surface and $200 \mathrm{~m}$ depth, i.e. in the the water entering into the Mediterranean (Knoery et al., 2013). These low $\mathrm{HgT}_{\mathrm{UNF}}$ concentrations in the $\mathrm{AW}$ mixed layer are likely due to both $\mathrm{Hg}$ evasion to the atmosphere and $\mathrm{Hg}$ scavenging by biological pumping in the stratified North Atlantic waters.

Thus, considering the $\mathrm{HgT}_{\mathrm{UNF}}$ concentration levels in $\mathrm{AW}$ and LIW, there is an important addition of $\mathrm{Hg}$ within the Northwestern Mediterranean to reach the concentrations observed in the WMDW. According to a simulation approach, applied to the 2012-2013 period, half of the dense water is formed from the transformation of LIW and former dense water, and half from AW (Waldman et al., 2016). However, formation of WMDW is annually variable and the proportions of LIW and AW in the WMDW at 
the time of our cruise are unknown. Thus, we conservatively estimate $\mathrm{HgT}_{\mathrm{UNF}}$ enrichment of WMDW relative to conservative mixing of LIW and AW as $\leq 0.1 \mathrm{pmol} \mathrm{L}{ }^{-1}$. A simple calculation can be done for estimating the $\mathrm{Hg}$ flux needed to increase the North Gyre water column $\mathrm{HgT}_{\mathrm{UNF}}$ concentration by $0.1 \mathrm{pmol} \mathrm{L}^{-1}$ : For a $2000 \mathrm{~m}$ deep water column the corresponding amount of $\mathrm{Hg}$ is $0.2 \mu \mathrm{mol} \mathrm{m}{ }^{-2}$. Considering a water residence time of 20 years in the Western Mediterranean basin (Béthoux et al., 2005), the minimum annual flux should be $10 \mathrm{nmol} \mathrm{m} \mathrm{yr}^{-1}$. Mercury deposition from the atmosphere, diffusion from sediments and continental shelf advection are candidate sources for this addition.

A bulk atmospheric wet deposition of $10.3 \mathrm{nmol} \mathrm{HgT} \mathrm{m}^{-2} \mathrm{yr}^{-1}$ was calculated from the mean concentration in rain $\left(31 \mathrm{pmol} \mathrm{L}^{-1}\right)$ and a precipitation average of $332 \mathrm{~mm} \mathrm{yr}^{-1}$ over the Northwestern Mediterranean Sea (Lebeaupin Brossier et al., 2012). Accordingly, the required flux for the estimatedHgT $\mathrm{T}_{\mathrm{UNF}}$ enrichment in WMDW is equivalent to the entire wet deposition or to one third of the total $\mathrm{Hg}$ atmospheric deposition calculated in the previous section 5.1.4.

Addition of $\mathrm{Hg}$ from a sediment source would be consistent with findings by Ogrinc et al. (2007), who proposed a potential $\mathrm{Hg}$ diffusive flux from the Northwestern Mediterranean sediment to the overlying water column in the same order of magnitude $\left(18 \mathrm{nmol} \mathrm{m}^{-2} \mathrm{yr}^{-1}\right)$. However, a diffusive flux of dissolved $\mathrm{Hg}$ is unlikely, since the uppermost layers of the continental rise and abyssal plain sediments in the North Gyre of the Northwestern Mediterranean are known to be oxic down to several $\mathrm{cm}$ below the sediment-water interface (Buscail et al, 1997). In fact, $\mathrm{Hg}$ diffusion out of the sediment has never been demonstrated for such oxic environments, where oxyhydroxides are thought to act as a trap for diffusing species at the benthic interface (e.g., Bothner et al., 1980; Gobeil and Cossa, 1993; Feyte et 
al., 2010). However, deep convection, such as the one occurring in winter 2011, is known to cause resuspension of deep-sea sediments, followed by vertical mixing in the whole water column (Stabholz et al., 2013; Puig et al., 2013), making a sedimentary source plausible. In the absence of any quantitative evaluation of such resuspension processes on the annual scale, the resulting $\mathrm{Hg}$ release to the water column remains unknown.

Mercury advection from the shelf could also contribute to the WMDW Hg enrichment. Although there is no signal in the HgT vertical profiles supporting the idea of a large continental shelf $\mathrm{Hg}$ advection within the North Gyre (Fig. 5), the $\mathrm{HgT}_{\mathrm{UNF}}$ mean concentration in the deep profiles near the foot of the slope calculated from 2006 data (1.29 \pm 0.17 pmol L ${ }^{-1} ; \mathrm{n}=27$; Fig. S5) is significantly higher $(t$-test; $p<0.01)$ than the average WMDW HgT $\mathrm{TNF}_{\mathrm{UNF}}$ concentration $\left(1.11 \pm 0.06 \mathrm{pmol} \mathrm{L}^{-1}, \mathrm{n}=60\right)$. However, advection from the shelf would not affect the dissolved phase, since the lowest $\mathrm{HgT}_{\mathrm{F}}$ concentrations occur on the shelf (Stas. B, C and D, Fig. 4a) and $\mathrm{HgT}_{\mathrm{UNF}}$ distributions at the edge of the shelf point to the presence of substantial amounts of particulate $\mathrm{HgT}$, especially near the bottom of the water column during the monitored stormy downwelling period (Sta. X, Fig. 4b). According to our calculation (see section 5.1.3), the amount of $\mathrm{Hg}$ advected from the shelf to the North Gyre deep waters, during the March 2011 downwelling event, was $\sim 0.2 \mathrm{kmol}$, i.e., $\sim 60 \%$ of the particulate $\mathrm{Hg}$ escaping the shelf each year. Atmosphere, deep-sediment resuspension and shelf are, thus, the most probable sources of the $\mathrm{Hg}$ enrichment in the WMDW. However, more research is needed to solve that issue. Whatever the Hg-enrichment source is, the WMDW, which is advected westward through the Gibraltar Strait, constitutes a Hg source for the North Atlantic Ocean. 
Acknowledgments: Thanks are due to Bernard Averty, Jean-François Chiffoleau, Nicole Garcia, Christine Sotin and Roger Kerouel who participated in sampling and/or analytical works and to the captains and crews of the R/V SUROIT (BIOPRHOFI cruise) and the R/V Atalante (CASCADE cruise). Special thanks to François Dufois and Francesca Sprovieri for their helpful comments. This research benefited from funding by the French National Research Agency (EXTREMA project, N ANR-06-VULN-005), and European Commission’s Seventh Framework Program (HERMIONE project, $\left.N^{\circ} 226354\right)$. This study was carried out as a part of the WP3 MERMEX/MISTRALS program and is a contribution to the international LOICZ projects.

\section{References}

Aminot A. and Kérouel K. (2007) Dosage automatique des nutriments dans les eaux marines : méthodes en flux continu. Méthodes d'analyse en milieu marin. Editions Quae. 187 pages. ISBN 978-2-7592-0023-8.

Amyot M., Gill G. A. and Morel F. M. M. (1997) Production and loss of dissolved gaseous mercury in coastal seawater. Environ. Sci. Technol. 31, 3606-3611.

Andersson M. E., Gărdfeldt K., Wängberg I., Sprovieri F., Pirrone N. and Lindqvist O. (2006) Seasonal and daily variation of mercury evasion at coastal and off shore sites from the Mediterranean Sea. Mar. Chem., 107, 103-116.

Balcom P. H., Hammerschmid C. R., Fitzgerald W. F., Lamborg C. H. and O'Connor J. S. (2008) Seasonal distributions and cycling of mercury and methylmercury in the waters of New York/New Jersey Harbor Estuary. Mar. Chem., 109, 1-17.

Béthoux J.-P., El Boukhary M. S., Ruiz-Pino D., Morin P. and Copin-Montégut C. (2005) Nutrient, oxygen and carbon ratios, $\mathrm{CO}_{2}$ sequestration and anthropogenic forcing in the 
Mediterranean Sea, p. 67-86. In, The Mediterranean Sea. Handbook of Environmental Chemistry, Vol 5. Saliot, A. editeur. Springer, 413 p. ISSN 1433-6863.

Bloom N. S. and Crecelius E. A. (1983) Determination of mercury in seawater at subnanogram per liter levels. Mar. Chem., 14, 49-59.

Bothner M. H., Jahnkem R. A., Peterson L. and Carpenter R. (1980) Rate of mercury loss from contaminated estuarine sediments. Geochim. Cosmochim. Acta, 44, 273-285.

Bourrin F., Durrieu de Madron X., Heussner S. and Estournel C. (2008) Impact of winter dense water formation on shelf sediment erosion (evidence from the Gulf of Lions, NW Mediterranean). Cont. Shelf Res., 28, 1984-1999.

Bourrin F., Many G., Durrieu de Madron X., Martín J., Puig P., Houpert L., Testor P., Kunesch S., Mahiouz K. and Béguery L. (2015) Glider monitoring of shelf suspended particle dynamics and transport during storm and flooding conditions. Cont. Shelf Res., 109, 135-49.

Buscail R., Ambatsian P., Monaco A. and Bernat M. (1997) ${ }^{210} \mathrm{~Pb}$, manganese and carbon indicators of focusing processes on the Northwestern Mediterranean continental margin. Mar. Geol., 137, 271-286.

Canals M., Puig P., Durrieu de Madron X., Heussner S., Palanques A., Fabres J. (2006) Flushing submarine canyons. Nature, 444, 354-357.

Castelle S. (2010) Suivi des apports en mercure au Golfe du Lion par voies atmosphérique et fluvial. Rapport Ifremer $\mathrm{N}^{\circ} \mathrm{RST}$.DOP/BE /LBCM/025.

Cathalot C., Rabouille, Pastor L., Deflandre B., Viollier E., Buscail R., Grémare A., Treignier C. and Pruski A. (2010) Temporal variability of carbon recycling in coastal sediments influenced by rivers: assessing the impact of flood inputs in the Rhône River prodelta. Biogeosciences, 7, 1187-1205.

Charmasson S., Radakovitch O., Arnaud M., Bouisset P. and Pruchon A. S. (1998) Long-core profiles of ${ }^{137} \mathrm{Cs},{ }^{134} \mathrm{Cs},{ }^{60} \mathrm{Co}$ and ${ }^{210} \mathrm{~Pb}$ in sediment near the Rhône river (Northwestern Mediterranean Sea). Estuaries, 21, 367-378. 
Choe K.-Y. and Gill G. A. (2003) Distribution of particulate, colloidal, and dissolved mercury in San Francisco Bay estuary. 2. Monomethyl mercury. Limnol. Oceanogr., 48, 1547-1556.

Conan P., Pujo-Pay M., Raimbault P. and Leveau M. (1998) Variabilité hydrologique et biologique du golfe du Lion. II. Productivité sur le bord interne du courant. Oceanol. Acta, 21, 767-782.

Coquery M., Cossa D. and Sanjuan J. (1997) Speciation and Sorption of Mercury in Two Macro-Tidal Estuaries. Mar. Chem., 58, 213-227.

Cossa D., Gobeil C., Courau P. (1988) Dissolved Mercury Behavior in the Saint-Lawrence Estuary. Est. Cstl. Shelf Sci., 26, 227-230.

Cossa D. and Martin J.-M. (1991) Mercury in the Rhone delta and adjacent marine areas. Mar. Chem., 36, 291-302.

Cossa D., Coquery M., Gobeil C. and Martin J.-M. (1996) Mercury Fluxes at the Ocean Margins. 229-247. In: Regional and Global Cycles of Mercury: Sources, Fluxes, and Mass Balances. W. Baeyens, R. Ebinghaus and O. Vasiliev éditeurs. Kluwer Academic Publishers, Dordrecht, The Netherlands.

Cossa D., Averty B., Breaudeau J. and Senard A.-S. (2003) Spéciation du mercure dissous dans les eaux marines. Analytical methods for the marine environments. Ifremer and French Ministry for Ecology and Sustainable Development publication MA0303.

Cossa D., M.H. Cotté-Krief M.-H., Mason R.P. and Bretaudeau-Sanjuan J. (2004) Total mercury in the water column near the shelf edge of the European continental margin. Mar. Chem., 90, 21-29.

Cossa D. and Coquery M. (2005) The Mediterranean mercury anomaly, a geochemical or a biological issue. pp 177-208. In: The Mediterranean Sea. Handbook of Environmental Chemistry, Vol 5. Saliot, A. editeur. Springer, 413 p. ISSN 1433-6863.

Cossa D., Durrieu de Madron X., Schäfer J., Lanceleur L., Guédron S., Buscail R., Thomas B., Castelle S. and Naudin J.-J. (2017) The open sea as the main source of methylmercury in the water column of the Gulf of Lions (Northwestern Mediterranean margin). Geochim. Cosmochim. Acta, 199, 222-237. 
Cossa D., Fanget A.-S., Chiffoleau J.-F., Bassetti M.-A., Buscail R., Dennielou B., Briggs K., Arnaud M., Guédron S. and Berné S. (2017) Chronology and sources of trace elements accumulation in the Rhône pro-delta sediments (Northwestern Mediterranean) during the last 400 years. Progr. Oceanogr., present issue.

Diaz F., Naudin J.-J., Courties C., Rimmelin P. and Oriol L. (2008) Biogeochemical and ecological functioning of the low-salinity water lenses in the region of the Rhone River freshwater influence, NW Mediterranean Sea. Cont. Shelf Res., 28, 1511-1526.

Dufois F. (2008) Sediment transport modelling in the Gulf of Lions with the perspective of studying the fate of radionuclides from the Rhone River. $\mathrm{PhD}$ thesis. Universite du Sud Toulon-Var, France.

Dufois F., Verney R., LeHir P., Dumas F. and Charmasson S. (2014) Impact of winter storms on sediment erosion in the Rhône River prodelta and fate of sediment in the Gulf of Lions (North Western Mediterranean Sea). Cont. Shelf Res., 72, 57-72.

Dumas C., Aubert D., Durrieu de Madron X., Ludwig W., Heussner S., Delsaut N., Menniti C., Sotin C. and Buscail R. (2014) Storm-Induced transfer of particulate trace metals to the deep-sea in the Gulf of Lion (NW Mediterranean Sea). Environ. Geochem. Health, 36, 995-1014.

Durrieu de Madron X., Abassi A., Heussner S., Monaco A., Aloïsi J.-C., Radakovitch O., Giresse P., Buscail R. and Kerhervé Ph. (2000) Particulate matter and organic carbon budgets for the Gulf of Lions (NW Mediterranean). Oceanol. Acta, 23, 717-730.

Durrieu de Madron X., Denis L., Diaz F., Garcia N., Guieu C., Grenz C., Loÿe-Pilot M.-D., Ludwig W., Moutin T., Raimbault P. and Ridame C. (2003) Nutrients and carbon budgets for the Gulf of Lion during the Moogli cruises. Oceanol. Acta, 26, 421-433.

Durrieu de Madron X., Wiberg P. L. and Puig P. (2008) Sediment dynamics in the Gulf of Lions: The impact of extreme events. Cont. Shelf Res., 28, 1867-1876.

Durrieu de Madron X., Houpert L., Puig P., Sanchez-Vidal A., Testor P., Bosse A., Estournel C., Somot S., Bourrin F., Bouin M. N., Beauverger M., Beguery L., Calafat A., Canals M., Coppola L., Dausse D., D'Ortenzio F., Font J., Heussner S., Kunesch S., Lefevre D., Le Goff H., Martín J., Mortier L., Palanques A. and Raimbault P. (2013) Interaction of dense 
shelf water cascading and open-sea convection in the Northwestern Mediterranean during winter 2012. Geophys. Res. Lett., 40, 1379-1385, doi:10.1002/grl.50331.

Elbaz-Poulichet F., Garnier J.-M., Guan D. M., Martin J.-M. and Thomas A. J. (1996) The conservative behaviour of trace metals $(\mathrm{Cd}, \mathrm{Cu}, \mathrm{Ni}$ and $\mathrm{Pb})$ and as in the surface plume of stratified estuaries: Example of the Rhône river (France). Estuar. Coast. Shelf Sci., 42, 289310.

Elbaz-Poulichet F., Dezileau L., Freydier R., Cossa D., Sabatier P. (2011) A 3500-year record of $\mathrm{Hg}$ and $\mathrm{Pb}$ contamination in a Mediterranean sedimentary archive (the Pierre Blanche Lagoon, France). Environ. Sci. Technol., 45, 8642-8647.

Estournel C., Durrieu de Madron X., Marsaleix P., Auclair F., Julliand C. and Vehil R. (2003) Observations and modelisation of the winter coastal oceanic circulation in the Gulf of Lions under wind conditions influenced by the continental orography (FETCH experiment). J. Geophys. Res., 108, C3, 8059.

Eyrolle F., Radakovitch O., Raimbault P., Charmasson S., Antonelli C., Ferrand E., Aubert D., Raccasi G., Jacquet S. and Gurriaran R. (2012) Consequences of hydrological events on the delivery of suspended sediment and associated radionuclides from the Rhône River to the Mediterranean Sea. J. Soils Sediments, 12, 1479-1495.

Ferrarra, R., Ceccarini C., Lanzillotta E., Gardfeldt K., Sommar J., Horvat M., Logar M., Fajon V., Kotnik J. (2003). Profiles of dissolved gaseous mercury concentration in the Mediterranean seawater. Atmos. Environ., 37, S85-S92.

Feyte S., Tessier A., Gobeil C. and Cossa D. (2010) In situ adsorption of mercury, methylmercury and other elements by iron oxyhydroxides and organic matter in lake sediments. Appl. Geochem., 25, 984-995.

Fitzgerald W. F. and Lamborg, C. H. (2005) Geochemistry of mercury in the environment. In: Holland, H., Turekian, K. (Eds.), Environmental Geochemistry, Vol. 9 of Treatise on Geochemistry. Elsevier, pp. 107-148 (Chapter 4).

Fitzgerald W. F., Lamborg C. H. and Hammerschmidt C. R. (2007) Marine biogeochemical cycling of mercury. Chem. Rev., 107, 641-662. 
Gairoard S., Radakovitch O., Eyrolle F., Ludwig W. and Cossa D. (2012) Flux de matière solides et liquides des bassins versants français à la Méditerranée. Rapport IRSN, CEREGE, UPVD, IFREMER à l'AERMC, Septembre 2012. 87 pages.

Gencarelli C. N., de Simone F., Hedgecock I. M., Francesca Sprovieri F., Yang X., Pirrone N. (2015) European and Mediterranean mercury modelling : Local and long range contributions to the deposition flux. Atmos. Environ., 117, 162-168.

Gill G. A. and Fitzgerald W. F. (1988) Vertical mercury distribution in the oceans. Geochim. Cosmochim. Acta, 52, 1719-1728.

Gobeil C. and Cossa D. (1993) Mercury in the sediments and sediment pore waters in the Laurentian trough. Can. J. Fish. Aquat. Sci., 50, 1794-1800.

Guédron S., Huguet L., Vignati D. A. L., Liu B., Gimbert F., Ferrarin B. J. D., Zonta R.and Dominik J. (2012) Tidal cycling of mercury and methylmercury between sediments and water column in the Venice Lagoon (Italy). Mar, Chem., 130-131, 1-11.

Guizien K. (2009) Spatial Variability of Wave Conditions in the Gulf of Lions (NW Mediterranean Sea). Vie et Milieu-Life and Environment, 59, 261-270.

Hammerschmidt C. R., Lamborg C. H. and Fitzgerald W. F. (2007) Aqueous phase methylation as a potential source of methylmercury in wet deposition. Atmos. Environ., 41, 1663-1668.

Harmelin-Vivien M., Dierking J., Banaru D., Fontaine M. F. and Arlhac D. (2010) Seasonal variation in stable $\mathrm{C}$ and $\mathrm{N}$ isotope ratios of the Rhone River inputs to the Mediterranean Sea (2004-2005). Biogeochemistry, 100, 139-150.

Hood E. M., Sabine, C. L., and Sloyan B. M., eds. (2010) The GO-SHIP Repeat Hydrography Manual: A Collection of Expert Reports and Guidelines. IOCCP Report Number 14, ICPO Publication Series Number 134.

Horvat M., Lupsina V. and Pihlar B. (1991) Determination of total mercury in coal fly ash by gold amalgamation cold vapour atomic absorption spectrometry. Anal. Chim. Acta, 243, 71-79. 
Jany C. and Zebraki M. (2012) Metroc : Evaluation des apports de contaminants chimiques de la métropole marseillaise au milieu marin. Rapport Ifremer RST.ODE/LER/PAC/1202. Conventions AERMC-IFREMER N²007-1745 et 2009-0351.

Knoery J., Marusczak N., Thomas B., de Vogüe B., Cossa D., Ammoscato I., Horvat M. and Pirrone N. (2013) New Methyl Mercury Speciation Data from the Western Mediterranean Water-Column: Preliminary Results from the FENICE 2012 Cruise. ICMGP, Edinburgh, July 2013.

Lamborg C. H., Hammerschmidt C. R., Bowman K. L., Swarr G. J., Munson K. M., Ohnemus D. C., Lam P. J., Heimbürger L.-E., Rijkenberg M. J. A. and Saito M. A. A. (2014) A global ocean inventory of anthropogenic mercury based on water column measurements. Nature, 512, 65-68.

Lansard B. (2005) Distribution et remobilisation du plutonium dans les sédiments du prodelta du Rhône (Méditerranée nord occidentale). PhD Thesis (Sciences de l'Environnement Marin), Université Aix-Marseille II, France.

Lansard B., Grenz C., Charmasson S., Schaaff E. and Pinazo C. (2006) Potential plutonium remobilisation linked to marine sediment resuspension: First estimates based on flume experiments. J. Sea Res., 55, 74-85.

Launay M. (2014) Flux de contaminants particulaires dans un grand cours d'eau anthropisé: dynamique des PCB et du mercure transportés par les matières en suspension du Rhône, du Léman à la Méditerranée. Thèse de doctorat de l’Université de Lyon, France.

Laurier F. J. G., Mason R. P., Whalin L. and Kato S. (2003) Reactive gaseous mercury formation in the North Pacific Ocean's marine boundary layer: A potential role of halogen chemistry. J. Geophys. Res., 108, D17, 4529, doi:10.1029/2003JD003625, 2003.

Laurier F. J. G., Cossa D., Beucher C. and Brévière E. (2007) The impact of groundwater discharges on mercury partitioning, speciation and bioavailability to mussels in a coastal zone. Mar. Chem., 104, 143-155.

Lebeaupin Brossier C., Béranger K. and Drobinski P. (2012) Ocean response to strong precipitation events in the Gulf of Lions (northwestern Mediterranean Sea): a sensitivity study. Ocean Dynamics, 62, 213-226. 
Many G., Bourrin F., Durrieu de Madron X., Pairaud I., Gangloff A., Doxaran D., Ody A., Verney R., Menniti C., Le Berre D., Jacquet M. (2016) Particle assemblage characterization in the Rhone River ROFI. J. Mar. Syst., 157, 39-51.

Maillet G. M., Vella C., Berné S., Friend P. L., Amos C. L., Fleury T. J. and Normand A. (2006) Morphological changes and sedimentary processes induced by the December 2003 flood event at the present mouth of the Grand Rhône River (southern France). Mar. Geol., 234, 159-177.

Marion C., Dufois F., Arnaud M. and Vella C. (2010) In situ record of sedimentary processes near the Rhône River mouth during winter events (Gulf of Lions, Mediterranean Sea). Cont. Shelf Res., 30, 1095-1107.

Martin J., Durrieu de Madron X., Puig P., Bourrin F., Palanques A., Houpert L., Higueras M., Sanchez-Vidal A., Calafat A.M., Canals M., Heussner S., Delsaut N. and Sotin C. (2013) Sediment transport along the Cap de Creus Canyon flank during a mild, wet storm. Biogeosciences, 10, 3221-3239.

Marusczak N., Larose C., Dommergue A., Yumvihoze E., Lean D., Nedjai R. and Ferrarri C. (2011) Total mercury and methylmercury in high altitude surface snow from the French Alps. Sci. Total Environ., 409, 3949-3954.

Marusczak N., Castelle S, de Vogüé B, Knoery J. and Cossa D. (2015) Seasonal Variations of Total Gaseous Mercury at a French Coastal Mediterranean Site. Aerosol and Air Quality Research, doi:10.4209/aaqr.2015.04.0219.

Mason R. P. and Fitzgerald W. F. (1993) The distribution and biogeochemistry cycling of mercury in the Equatorial Pacific Ocean. Deep-Sea Res. I, 40, 1897-1924.

Mason R. P., Rolfhus K. R. and Fitzgerald W. F. (1998) Mercury in the North Atlantic Mar. Chem., 61, 37-53.

Mason R. P., Choi A. L., Fitzgerald W. F., Hammerschmidt C. R., Lamborg C. H., Soerensen A. L. and Sunderland E. M. (2012) Mercury biogeochemical cycling in the ocean and policy implications. Environ. Res., 119, 101-117. 
Millot C. and Taupier-Letage I. (2005) Circulation in the Mediterranean Sea, p. 29-66. In: The Mediterranean Sea. Handbook of Environmental Chemistry, Vol 5. Saliot, A. editeur. Springer, 413 p. ISSN 1433-6863.

Morel A. and André J.-M. (1991) Pigment distribution and primary production in the western Mediterranean as derived and modeled from coastal zone color scanner observations. $J$. Geophys. Res. (Oceans), 96, 12685-12698.

Muresan B., Cossa D., Coquery M. and Richard S. (2008) Mercury sources and transformations in a man-perturbed tidal estuary: The Sinnamary Estuary, French Guiana. Geochim. Cosmochim. Acta, 72, 5416-5430.

Murphy J. and Riley J. P. (1962) A modified single solution methode for the determination of phosphates in natural waters. Anal. Chem. Acta, 27, 31-36.

Naudin J.-J., Cauwet G., Chrétiennot-Dinet M.-J., Deniaux B., Devenon J.-L. and Pauc H. (1997) River discharges and wind influence upon particulate transfer at the land-ocean interaction: case study of the Rhône River plume. Estuar. Coast. Shelf Sci., 45, 303-316.

Naudin J.-J. and Cauwet G. (1997) Transfer mechanisms and biogeochemical implications in the bottom nepheloid layer. A case study of the coastal zone off the Rhône River (France). Deep-Sea Res. II, 44, 551-575.

Noël M. (1996) Le plutonium traceur du transfert et de l'accumulation des apports particulaires du Rhône en Méditerranée Nord Occidentale. Thèse de doctorat, Université Paris XII, France.

Noh S., Choi M., Kim E., Dan N. P., Thanh B. X., Van Ha N. T., Sthiannopkao S. and Han S. (2013) Influence of salinity intrusion on the speciation and partitioning of mercury in the Mekong River Delta. Geochim. Cosmochim. Acta, 106, 379-390.

Ogrinc N., Monperrus M., Kotnik J., Fajon V., Vidimova K., Amouroux D., Kocman D., Tessier E., Žižek S. and Horvat M. (2007) Distribution of mercury and methylmercury in deep-sea surficial sediments of the Mediterranean Sea. Mar. Chem., 107, 31-48.

Ollivier P., Claude C., Radakovitch O. and Hamelin B. (2008) TIMS measurements of ${ }^{226}$ Ra and ${ }^{228} \mathrm{Ra}$ in the Gulf of Lion, an attempt to quantify submarine groundwater discharge. Mar. Chem., 109, 337-354. 
Ormaza-Gonzales F. I. and Statham P. J. (1996) A comparison of methods for the determination of dissolved and particulate phosphorus in natural waters. Water Res., 30, 2739-2747.

Palanques A., Durrieu de Madron X., Puig P., Fabres J., Guillén J., Calafat A., Canals M. and Bonnin J. (2006) Suspended sediment fluxes and transport processes in the Gulf of Lions submarine canyons. The role of storms and dense water cascading. Mar. Geol., 234, 43-61.

Palanques A., Puig P., Latasa M. and Scharek R. (2009) Deep sediment transport induced by storms and dense shelf-water cascading in the northwestern Mediterranean basin. Deep-Sea Res. I, 56, 425-434.

Pastor L., Deflandre B., Viollier E., Cathalot C., Metzger E., Rabouille C., Escoubeyrou K., Lloret E., Pruski A. M., Vétion G., Desmalades M., Buscail R. and Grémare A. (2011) Influence of the organic matter composition on benthic oxygen demand in the Rhône River prodelta (NW Mediterranean Sea). Cont. Shelf Res., 31, 1008-1019.

Petrenko A., Leredde Y. and Marsaleix P. (2005) Circulation in a stratified and wind-forced Gulf of Lions, NW Mediterranean Sea: in situ and modeling data. Cont. Shelf Res., 25, 727.

Pont D., Simonnet J. P. and Walter A. V. (2002) Medium-term changes in suspended sediment delivery to the ocean: Consequences of catchment heterogeneity and river management (Rhone River, France). Estuar. Coast Shelf Sci., 54, 1-18.

Pruski A. M., Buscail R., Bourgeois S., Vétion G., Coston-Guarini J. and Rabouille C. (2015) Biogeochemistry of fatty acids in a river-dominated Mediterranean ecosystem (Rhône River prodelta, Gulf of Lions, France): Origins and diagenesis. Org. Geochem., 83-84, 227-240.

Puig. P., Durrieu de Madron X., Salat J., Schroeder K., Martín J., Karageorgis A. P, Palanques A., Roullier F., Lopez-Jurado J. L., Emelianov M., Moutin T. and Houpert L. (2013) Thick bottom nepheloid layers in the western Mediterranean generated by deep dense shelf water cascading. Progr. Oceanogr., 111, 1-23.

Quémerais B., Cossa D., Rondeau B., Pham T. T., Gagnon P. and Fortin B. (1999) Sources and Fluxes of Mercury in the St. Lawrence River. Environ. Sci. Technol., 33, 840-849. 
Radakovitch O., Charmasson S., Arnaud M. and Bouisset P. (1999) Pb-210 and caesium accumulation in the Rhône delta sediments. Estuar. Coast. Shelf Sci., 48, 77-92. doi:10.1006/ecss. 1998.0405.

Stabholz M., Durrieu de Madron X., Canals M., Khripounoff A., Taupier-Letage I., Testor P., Heussner S., Kerhervé P., Delsaut N., Houpert L., Lastras G. and Dennielou B. (2013) Impact of open-ocean convection on particle fluxes and sediment dynamics in the deep margin of the Gulf of Lions. Biogeosciences, 10, 1097-1116.

Ulses C., Estournel C., Durrieu de Madron X. and Palanques A. (2008a) Sediment transport in the Gulf of Lion (NW Mediterranean): Impact of extreme storms and floods. Cont. Shelf Res., 28, 2048-2070.

Ulses C., Estournel C., Puig P., Durrieu de Madron X. and Marsaleix P. (2008b) Dense shelf water cascading in the northwestern Mediterranean during the cold winter 2005: Quantification of the export through the Gulf of Lion and Catalan margin. Geophys. Res. Letters, 35, L07610, doi:10.1029/2008GL033257.

UNEP (United Nations Environment Program). 2013. Global Mercury Report. Geneva, Switzerland: UNEP.

Vincent J., Laurent B., Losno R., Bon Nguyen, E., Roullet P., Sauvage S., Chevaillier S., Coddeville P., Ouboulmane N., Giorgio di Sarra A., Tovar-Sánchez A., Sferlazzo D., Massanet A., Triquet S., Morales Baquero R., Fornier M., Coursier C., Desboeufs K., Dulac F. and Bergametti G. (2016) Variability of mineral dust deposition in the western Mediterranean basin and south-east of France. Atmos. Chem. Phys. 16, 8749-8766.

Waldman R., Somot S., Herrmann M., Testor P., Estournel C., Sevault F. Prieur L., Mortier L., Coppola L., Taillandier V., Conan P. and Dausse D. (2016). Estimating dense water volume and its evolution for the year 2012-2013 in the North-western Mediterranean Sea: An observing system simulation experiment approach. J. Geophys. Res., DOI: 10.1002/2016JCO11694.

Walsh J. J. (1991) Importance of continental margins in the marine biogeochemical cycling of carbon and nitrogen. Nature, 350, 53-55 1991. 
Wängberg I., Munthe J., Amouroux D., Andersson M. E., Fajon V., Ferrara R., Gårdfeldt K., Horvat M., Mamane Y., Melamed E., Monperrus M., Ogrinc N., Yossef O., Pirrone N., Sommar J. and Sprovieri F. (2008) Atmospheric mercury at Mediterranean coastal stations. Environ. Fluid Mech., 8, 101-116.

Wanninkhof R. (1992) Relationship between wind speed and gas exchanges over the ocean. $J$ Geophys Res., 97, 7373-7382.

Whalin L., Kim E.-H. and Mason R. (2007) Factors influencing the oxidation, reduction, methylation and demethylation of mercury species in coastal waters. Mar. Chem., 107, 278-294.

Weiss-Penzias P. S., Ortiz C. Jr., Acosta R. P., Heim W., Ryan J. P., Fernandez D., Collett J. L. Jr. and Flegal A. R. (2012) Total and monomethyl mercury in fog water from the central California coast. Geophys. Res. Lett., 39, L03804, doi:10.1029/2011GL050324, 2012.

Wollast R., Chou, L. (2001) Ocean Margin EXchange in the Northern Gulf of Biscay: OMEX I. An introduction. Deep-Sea Res. II, 48, 2971-2978.

Žagar D., Sirnik N., Cetina M., Horvat M., Kotnik J., Ogrinc N., Hedgecock I. M., Cinnirella S., de Simone F., Gencarelli C. N., Pirrone N. (2013) Mercury in the Mediterranean. Part 2: Processes and mass balance. Environ. Sci. Pollut. Res. DOI $10.1007 / \mathrm{s} 11356-013-2055-5$. 


\section{Figure Captions}

Figure 1. Study site in the Northwestern Mediterranean, with main circulation patterns.

Stations location during CASCADE cruise (March 2011). Station coordinates are given in the Table S1.

Figure 2. Particulate $\mathrm{Hg}\left(\mathrm{HgT}_{\mathrm{P}}\right)$ versus Rhône River water discharge at station SORA (Arles). Relationship between solid-solution partitions of HgT and organic carbon (C) expressed on the basis of their partition coefficients $\left(\mathrm{K} d=\right.$ conc in solid / concentration in solution, $\mathrm{L} \mathrm{kg}^{-}$ $1)$.

Figure 3. Mercury in the freshwater-seawater mixing. Dissolved total $\mathrm{Hg}\left(\mathrm{HgT}_{\mathrm{F}}\right)$ versus salinity in (a) the estuarine mixing zone, (b) the Low Salinity Water lenses (LSW) drifting on the shelf.

Figure 4. Total $\mathrm{Hg}(\mathrm{HgT})$ vertical profiles in the water of the shelf and the continental slope of the Gulf of Lions. The UNF and F subscribes refer to unfiltered and filtered samples. (a) Shelf stations, (b) station $\mathrm{X}$ on the slope at the head of the Cap de Creus canyon, points associated with an asterisk refer to a time series recorded during the downwelling of shelf water.

Figure 5. Transect of potential temperature, salinity, dissolved oxygen and total $\mathrm{Hg}\left(\mathrm{HgT}_{\mathrm{UNF}}\right)$ in the North Gyre water column. M-transect and L-transect refer to North-South and WestEast sections, respectively (see Figure 1 and Table S1 for station localizations).

Figure 6. Mercury partition in the Northern Gyre. Vertical profiles of total $\mathrm{Hg}(\mathrm{HgT})$ at Stas. L-05 and L-10 in the North Gyre water column. F and P subscribes refer to dissolved and particulate phases, respectively. 


\section{Tables}

Table 1. A statistical summary of the concentrations in dissolved $\left(\mathrm{Hg}_{\mathrm{F}}<0.45 \mu \mathrm{m}\right)$ and particulate $\left(\mathrm{Hg}_{\mathrm{P}}>0.45 \mu \mathrm{m}\right) \mathrm{HgT}$ measured in the waters of the Rhône River at Arles (Sta. SORA). HgT values measured in 1994-1995 are from Cossa and Coquery (2005). SD: standard deviation; n: number of samples.

\begin{tabular}{lcc}
\hline & $\operatorname{HgT}_{\mathrm{F}}\left(\mathrm{pmol} \mathrm{L}^{-1}\right)$ & $\mathrm{HgT}_{\mathrm{P}}\left(\mathrm{nmol} \mathrm{g}^{-1}\right)$ \\
\hline & Period March 2009 - June 2010 (this study) \\
\hline Average $\pm \mathrm{SD}(\mathrm{n})$ & $2.45 \pm 2.05(24)$ & $0.85 \pm 0.45(27)$ \\
Min. - Max. & $0.40-9.25$ & $0.20-2.15$ \\
\hline & Period June 1994-June 1995 (Cossa and Coquery, 2005) \\
\hline Average \pm SD (n) & $5.30 \pm 2.95(24)$ & $2.40 \pm 2.00(24)$ \\
Min. - Max. & $1.40-16.50$ & $0.40-7.50$ \\
\hline
\end{tabular}

Table 2. Low Salinity Waters drifting (Lenses 1 and 2) on the shelf and slope waters (Sta. S230) (BIOPRHOFI cruise, see figure S2 for Sta. locations). A statistical summary of HgT measurements: average \pm standard deviation (number of samples) and range (Min. Max.).

\section{$\operatorname{HgT}\left(\mathrm{pmol} \mathrm{L}^{-1}\right)$}

Low Salinity Waters (1-50 m layer; bottom $\leq 120 \mathrm{~m}$ ) Filtered samples $(<0.4 \mu \mathrm{m})$

Slope Waters (< 100 m layer; bottom at $1386 \mathrm{~m}$ ), unfiltered samples

Slope Waters (100-900 m layer; bottom at $1386 \mathrm{~m}$ ), unfiltered samples

$$
1.57 \pm 0.74(84) \quad 0.61-3.50
$$

$$
1.22 \pm 0.13(3) \quad 0.98-1.35
$$

$$
1.41 \pm 0.06(4) \quad 1.33-1.48
$$


Table 3. (CASCADE cruise). Summary statistics for $\operatorname{HgT}_{\mathrm{UNF}}, \mathrm{HgT}_{\mathrm{F}}(<0.4 \mu \mathrm{m})$ concentrations in Gulf of Lions shelf, slope and North Gyre water samples. Average \pm Standard deviation (number of samples) and range (Min. - Max.). Station locations are indicated in Figure 1 and coordinates are given in Table S1. (*) Station X, located at the head of Cap de Creus canyon, was monitored during a storm event.

\begin{tabular}{|c|c|c|c|}
\hline $\begin{array}{l}\text { Station (water } \\
\text { layer sampled) }\end{array}$ & $\operatorname{HgT}_{\mathrm{F}}\left(\mathrm{pmol} \mathrm{L}^{-1}\right)$ & $\operatorname{HgT}_{\mathrm{UNF}}\left(\mathrm{pmol} \mathrm{L}^{-1}\right)$ & $\mathrm{HgT}_{\mathrm{F}} / \operatorname{HgT}_{\mathrm{UNF}}(\%)$ \\
\hline \multicolumn{4}{|c|}{ Inner shelf (bottom <100 m) } \\
\hline \multirow[t]{2}{*}{ A $(1-90 \mathrm{~m})$} & $1.20 \pm 0.89$ & $2.04 \pm 1.11(7)$ & $56 \pm 12(7)$ \\
\hline & $0.73-3.20$ & $1.27-4.47$ & $42-72$ \\
\hline \multirow[t]{2}{*}{ B (1-90 m) } & $0.65 \pm 0.13(10)$ & $1.17 \pm 0.29(10)$ & $57 \pm 14(10)$ \\
\hline & $0.49-0.88$ & $0.78-1.61$ & $43-89$ \\
\hline \multirow[t]{2}{*}{ C (1-90 m) } & $0.64 \pm 0.26(11)$ & $1.40 \pm 1.08(10)$ & $53 \pm 21(10)$ \\
\hline & $0.43-1.38$ & $0.58-4.20$ & $16-87$ \\
\hline \multirow[t]{2}{*}{$\mathrm{D}(1-90 \mathrm{~m})$} & $0.83 \pm 0.29(9)$ & $1.61 \pm 1.23(9)$ & $64 \pm 19(9)$ \\
\hline & $0.66-1.58$ & $0.92-3.80$ & $24-82$ \\
\hline \multirow[t]{2}{*}{$\mathrm{A} / \mathrm{B} / \mathrm{C} / \mathrm{D}(1-90 \mathrm{~m})$} & $0.80 \pm 0.47(37)$ & $1.52 \pm 1.00(36)$ & $58 \pm 17(36)$ \\
\hline & $0.43-3.20$ & $0.58-4.47$ & $16-89$ \\
\hline \multicolumn{4}{|c|}{ Slope edge and head of the Cap de Creus canyon (bottom at 100-300 m) } \\
\hline \multirow{2}{*}{$\mathrm{E}(2-290 \mathrm{~m})$} & $0.55 \pm 0.01(2)$ & $0.99 \pm 0.52(20)$ & $69 \pm 7(2)$ \\
\hline & $0.54-0.56$ & $0.58-2.94$ & $64-73$ \\
\hline \multirow[t]{2}{*}{$X^{*}(10-290 \mathrm{~m})$} & $1.11 \pm 0.50(7)$ & $1.83 \pm 0.66(28)$ & $63 \pm 12(7)$ \\
\hline & $1.05-1.16$ & $1.00-2.83$ & $45-80$ \\
\hline \multirow[t]{2}{*}{$\mathrm{L}-01(5-250 \mathrm{~m})$} & - & $1.07 \pm 0.10(6)$ & - \\
\hline & - & $1.00-1.26$ & - \\
\hline \multirow[t]{2}{*}{ M-12 (10-130 m) } & $1.09 \pm 0.20(4)$ & $1.02 \pm 0.12$ & $91 \pm 11(4)$ \\
\hline & $0.85-1.33$ & $0.93-1.14$ & $78-86$ \\
\hline
\end{tabular}




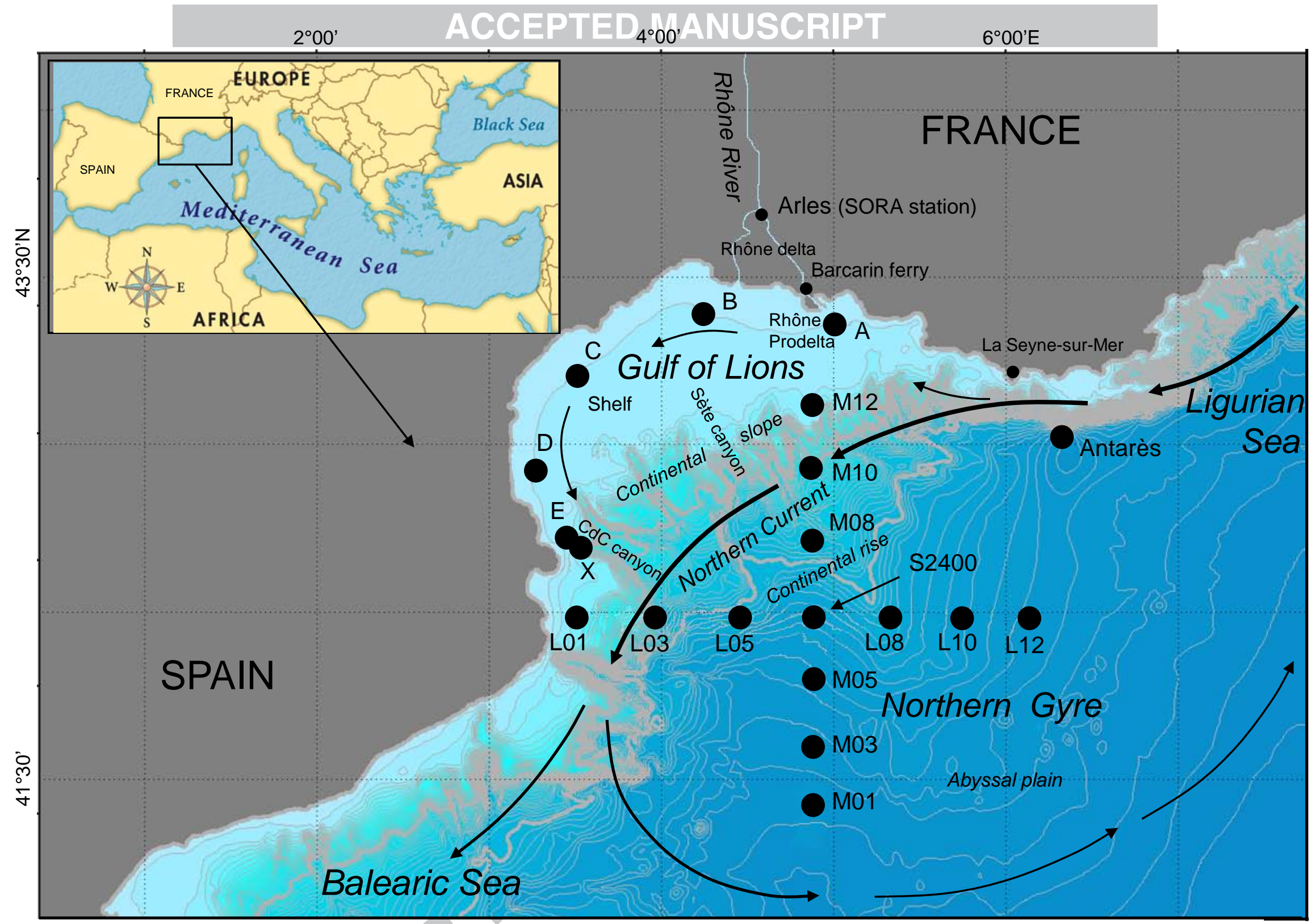

Fig. 1 


\section{ACCEPTED MANUSCRIPT}

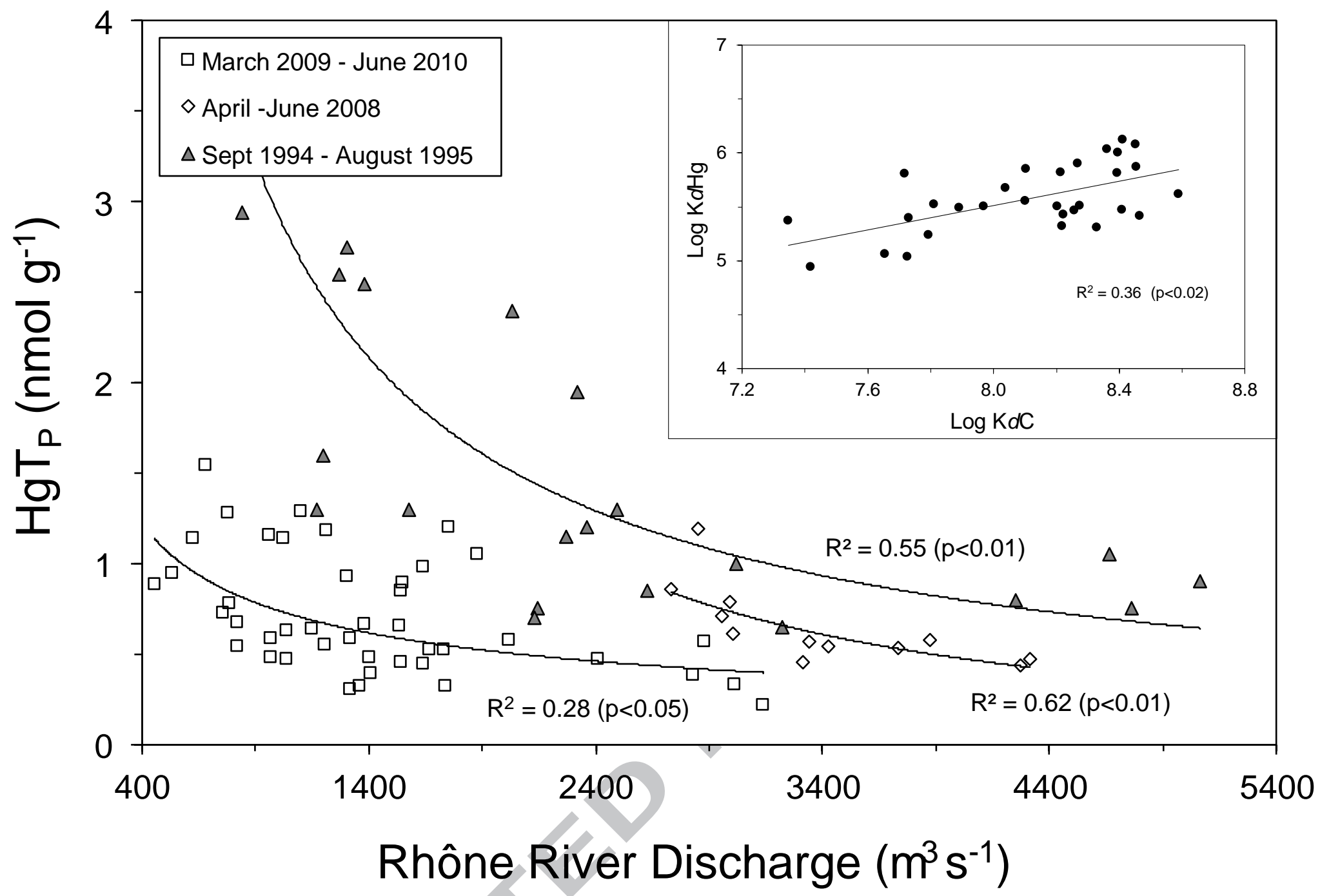

Fig. 2 


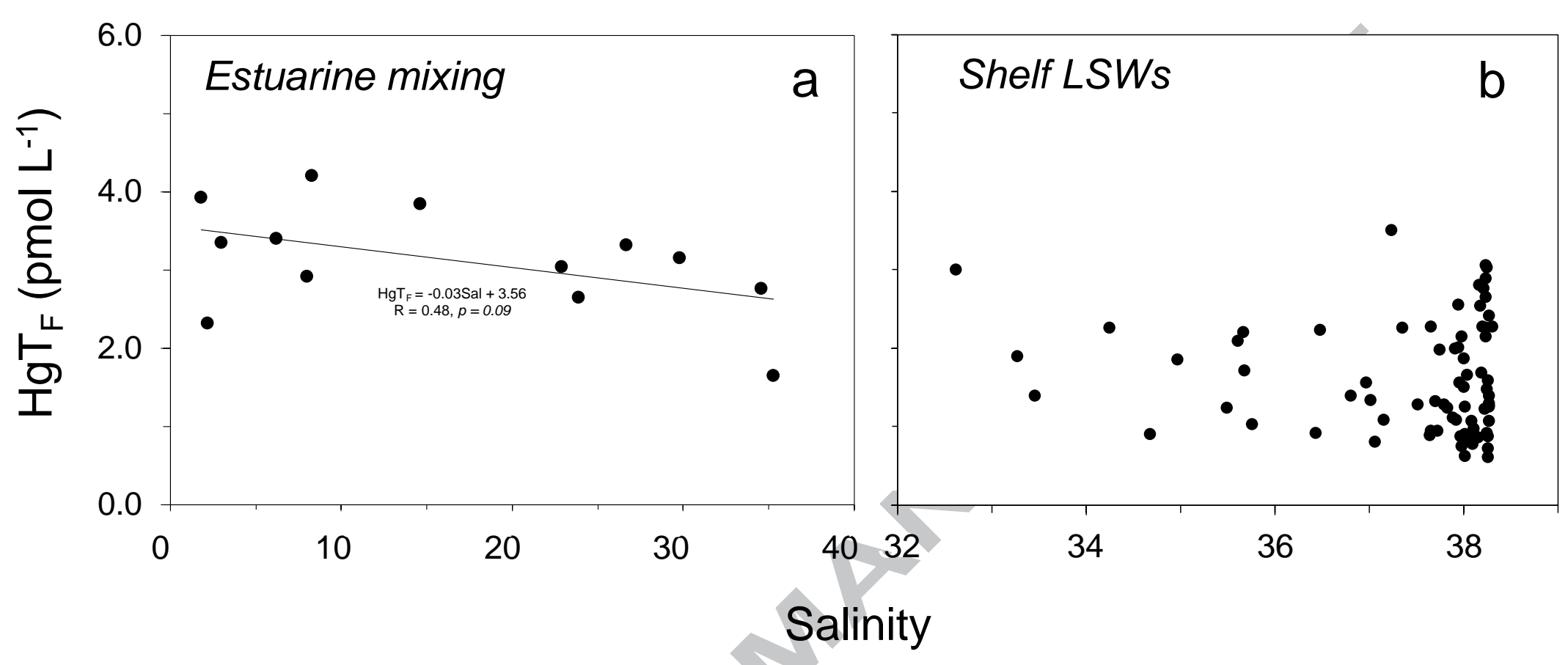

Fig. 3 


\section{ACCEPTED MANUSCRIPT}

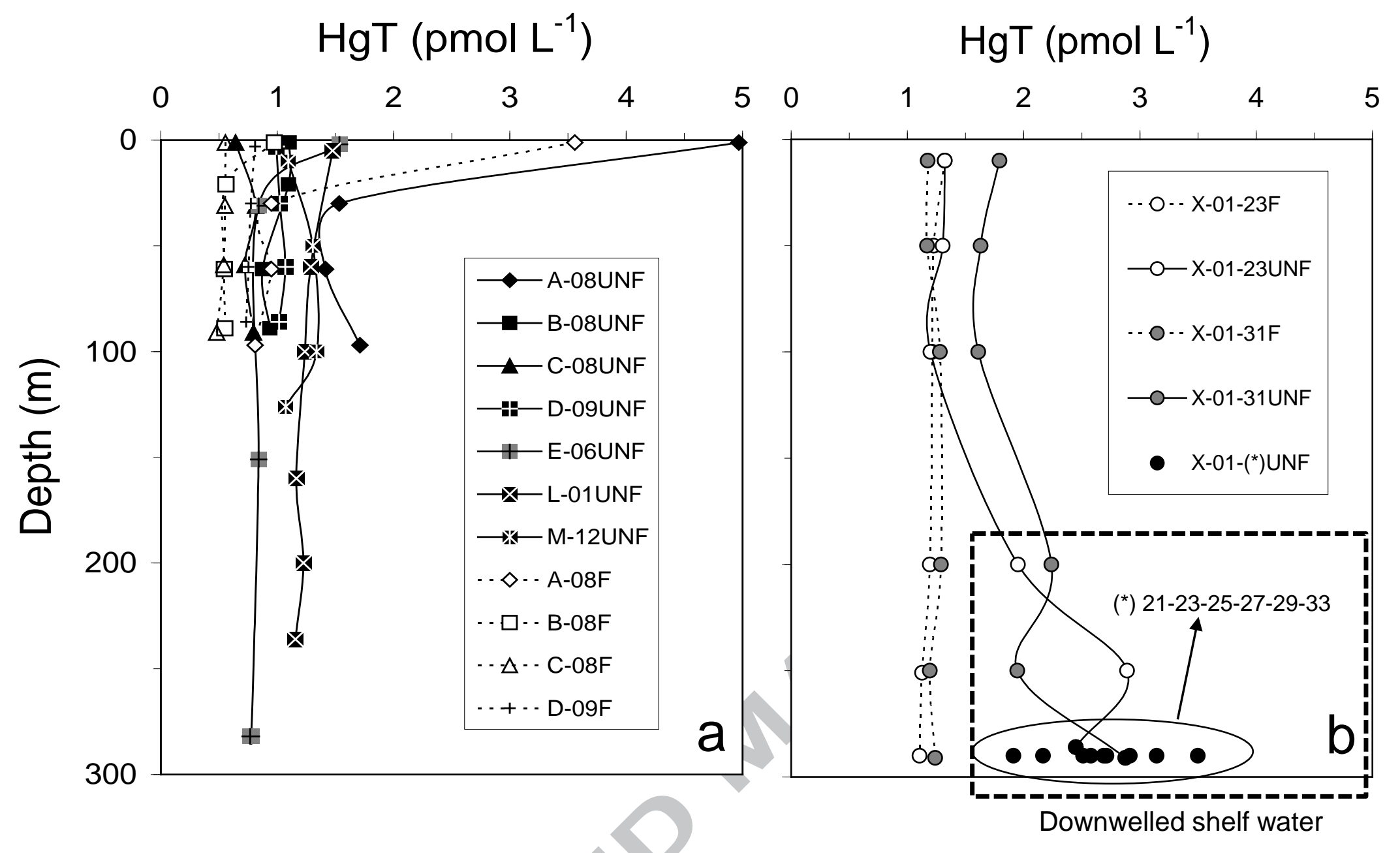

Fig. 4 


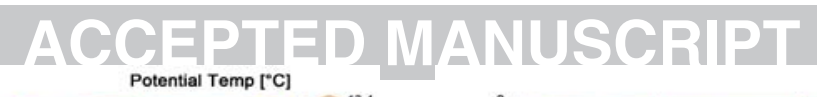
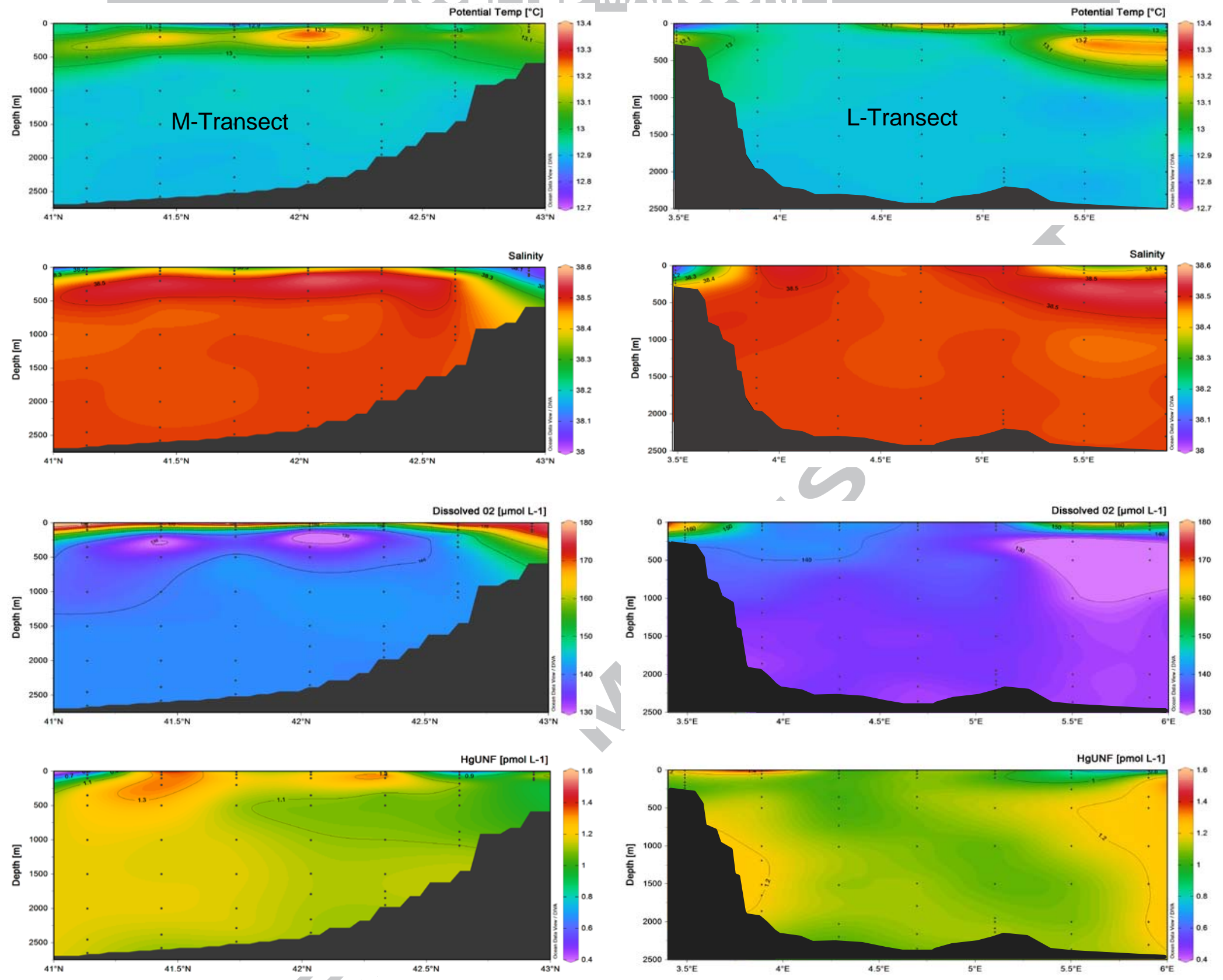

Fig. 5 


\section{HgT (pmol L-1)}

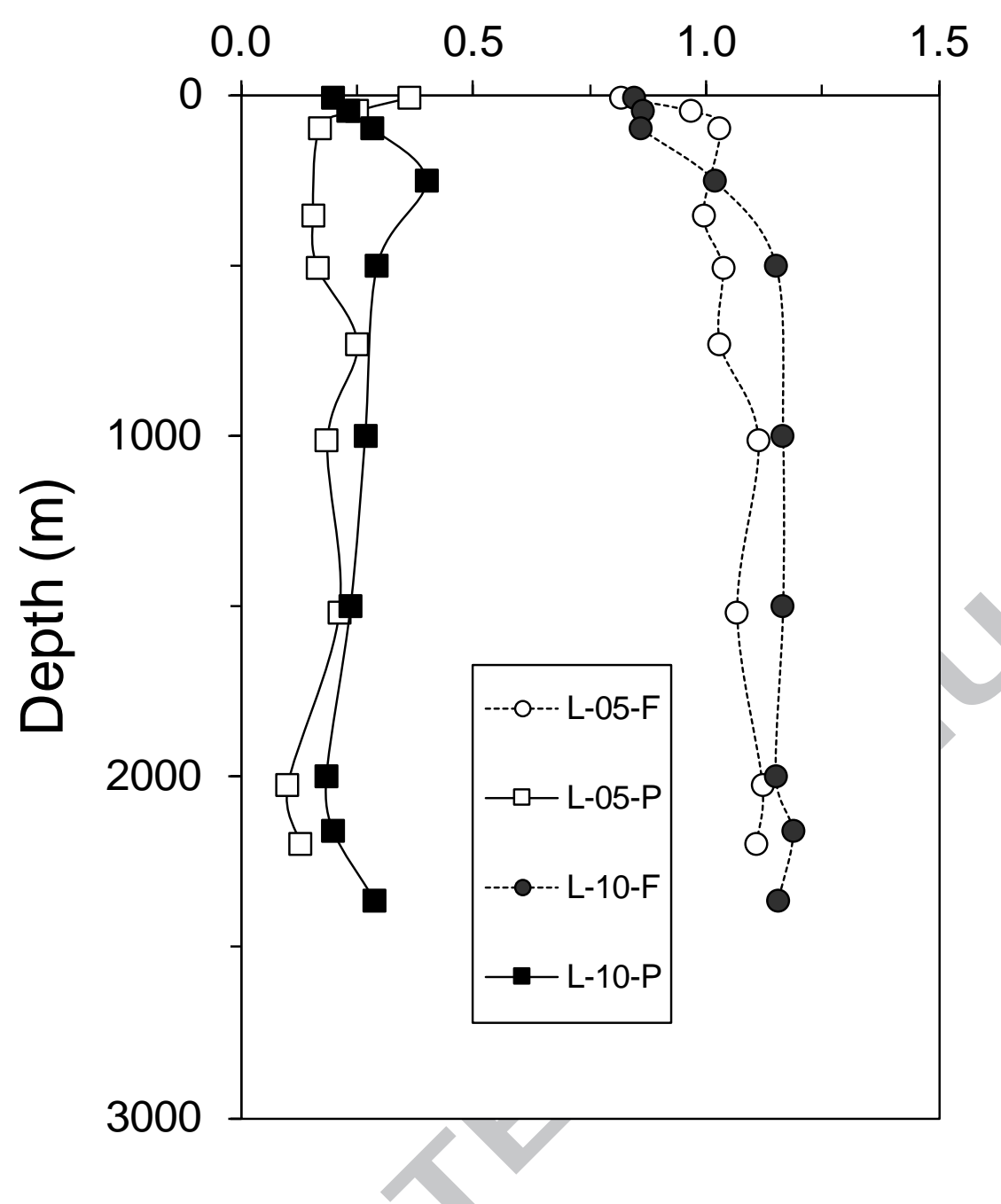

Fig. 6 